\title{
The Muscadine Grape (Vitis rotundifolia Michx) ${ }^{1}$
}

\author{
Peter C. Andersen, Ali Sarkhosh, Dustin Huff, and Jacque Breman ${ }^{2}$
}

\section{Introduction}

The muscadine grape is native to the southeastern United States and was the first native grape species to be cultivated in North America (Figure 1). The natural range of muscadine grapes extends from Delaware to central Florida and occurs in all states along the Gulf Coast to east Texas. It also extends northward along the Mississippi River to Missouri. Muscadine grapes will perform well throughout Florida, although performance is poor in calcareous soils or in soils with very poor drainage. Most scientists divide the Vitis genus into two subgenera: Euvitis (the European, Vitis vinifera L. grapes and the American bunch grapes, Vitis labrusca L.) and the Muscadania grapes (muscadine grapes). There are three species within the Muscadania subgenera (Vitis munsoniana, Vitis popenoei and Vitis rotundifolia). Euvitis and Muscadania have somatic chromosome numbers of 38 and 40, respectively. Vines do best in deep, fertile soils, and they can often be found in adjacent riverbeds.

Wild muscadine grapes are functionally dioecious due to incomplete stamen formation in female vines and incomplete pistil formation in male vines. Male vines account for the majority of the wild muscadine grape population. Muscadine grapes are late in breaking bud in the spring and require 100-120 days to mature fruit. Typically, muscadine grapes in the wild bear dark fruit with usually 4 to 10 fruit per cluster. Bronze-fruited muscadine grapes are also found in the wild, and they are often referred to as scuppernongs. There are hundreds of named muscadine grape cultivars from improved selections, and in fact, one that has been found in the Scuppernong River of North Carolina has been named 'Scuppernong. There are over 100 improved cultivars of muscadine grapes that vary in size from $1 / 4$ to $1 \frac{1 / 2}{2}$ inches in diameter and 4 to 15 grams in weight. Skin color ranges from light bronze to pink to purple to black. Flesh is clear and translucent for all muscadine grape berries.

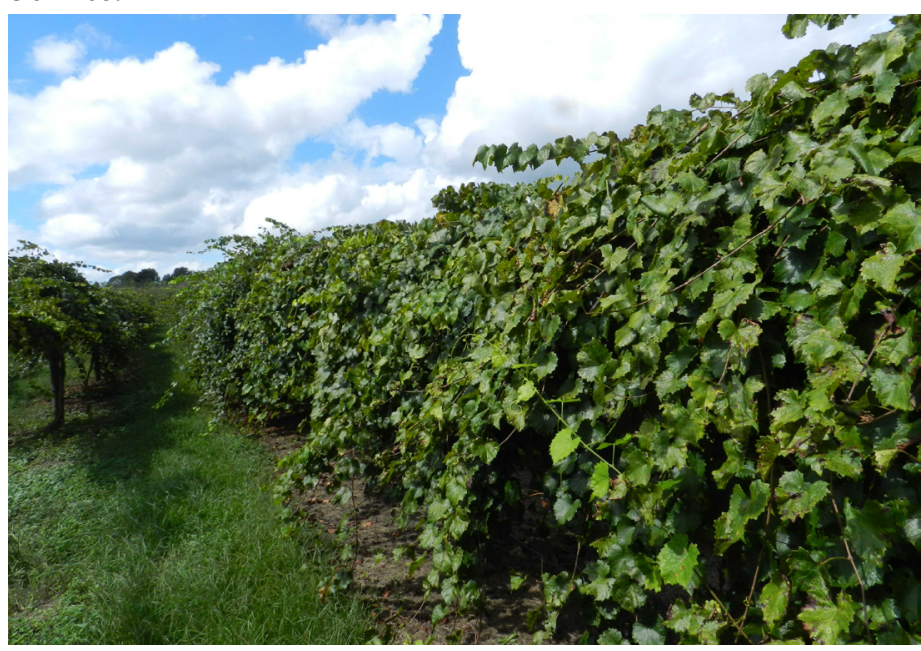

Figure 1. Mature muscadine grapevine. Credits: Peter C. Andersen, UF/IFAS

One reason for the popularity of muscadine grapes is that they are a sustainable fruit crop in the southeastern United States. They are tolerant of insect and disease pests, and homeowners can successfully grow muscadine grapes without spraying any pesticides. A distinct benefit

1. This document is HS763, one of a series of the Horticultural Sciences Department, UF/IFAS Extension. Publication date: June 2003. Revised November 2010, October 2013, January 2017, and October 2020. Visit the EDIS website at https://edis.ifas.ufledu for the currently supported version of this publication.

2. Peter C. Andersen, professor emeritus, UF/IFAS North Florida Research and Education Center-Quincy; Ali Sarkhosh, assistant professor and Extension specialist, Horticultural Sciences Department; Dustin Huff, biological scientist, Horticultural Sciences Department; and Jacque Breman, emeritus Extension agent IV, UF/IFAS Extension Columbia County; UF/IFAS Extension, Gainesville, FL 32611.

The Institute of Food and Agricultural Sciences (IFAS) is an Equal Opportunity Institution authorized to provide research, educational information and other services

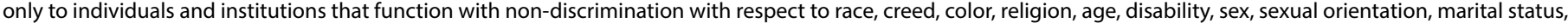
national origin, political opinions or affiliations. For more information on obtaining other UF/IFAS Extension publications, contact your county's UF/IFAS Extension office. U.S. Department of Agriculture, UF/IFAS Extension Service, University of Florida, IFAS, Florida A \& M University Cooperative Extension Program, and Boards of County Commissioners Cooperating. Nick T. Place, dean for UF/IFAS Extension. 
compared with European grapes (Vitis vinifera L.) is their natural resistance to Pierce's disease, caused by a bacterial pathogen called Xylella fastidiosa. This pathogen prevents the extensive cultivation of $V$. vinifera (common grape) in Florida. The commercial acreage in Florida is estimated to be 1,500 acres (USDA 2017). The most successful commercial plantings are comprised of large-fruited cultivars that are destined for the fresh market. U-Pick operations are common, and many growers market their product directly to the consumer using roadside markets, farmers markets, local sales, and other direct-to-consumer marketing strategies. Commercial muscadine vineyards that have been based on juice or wine grapes have generally not been very profitable because of low prices offered for muscadine grapes destined for processing. Muscadine grapes are notable for their high pigment and polyphenols, especially in thick skins. These polyphenols mainly include anthocyanins, tannins, quercetin, flacan-3-ols, gallic acid, ellagic acid, ellagic acid glycosides, ellagitannins, myricetin, and kaempferol.

\section{Cultivars}

Two categories of muscadine grapes will be discussed: recommended cultivars and those that are suggested for trial plantings. The vegetative and reproductive characteristics of recommended cultivars of muscadine grapes have been extensively tested in the southeastern United States and have stood the test of time. Many new cultivars appear to have good potential, but they have not been extensively tested, particularly in respect to consistent yield production. The performance of many grape cultivars in Florida is listed in Tables 1 to 3 . The majority of muscadine grape cultivars are not recommended in Florida due to a variety of reasons, including low or inconsistent yields, small berry size, poor flavor and/or thick skin, disease susceptibility, or a low percentage dry scar. The characteristics of the most important muscadine cultivars are summarized in Table 4.

A cultivar good for fresh-market consumption should be large, sweet, and attractive, with a relatively thin skin. Yields should be consistently moderate to high, and vine vigor and disease resistance should be satisfactory. Many cultivars are female with imperfect flowers and require a pollinizer. Pistillate (female) cultivars possess stamens that are not completely developed and are nonfunctional. Self-fertile cultivars often tend to yield $40 \%-50 \%$ higher than female cultivars.

A cultivar adapted for processing into wine, juice, or jelly must produce consistently high yields. Berries should contain at least $14^{\circ}$ Brix, should have a favorable sugar-acid ratio, and should taste good. Berry ripening should be uniform so that multiple harvests are not required. Juice and wine grapes (particularly red-skinned grapes) must have a high degree of color stability. Berry appearance is not critical. Mechanical pruning and harvesting must be employed for large-scale production due to a historically low return (about 20 cents/pound) for grapes destined to be processed.

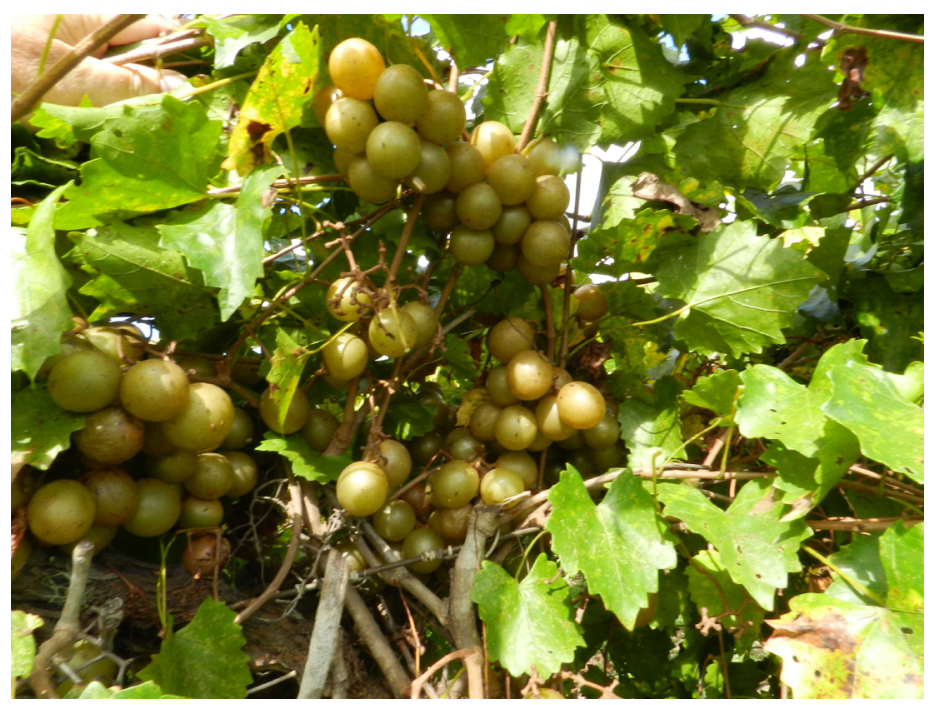

Figure 2. 'Granny Val' is a large, bronze grape recommended for fresh market.

Credits: Peter C. Andersen, UF/IFAS

\section{Recommended Cultivars for Fresh Market}

'Black Beauty': A pistillate cultivar that produces an attractive, very large, black berry grape of high overall quality. Berries are crunchy when ripe. Vine vigor and yield are moderate, and harvest is midseason.

'Black Fry': A pistillate cultivar that produces a large, black berry. Vine vigor and yield are in the moderate range. Harvest is early to midseason. It is reported to have leaf disease problems.

'Farrer': A pistillate cultivar that has produced well at the UF/IFAS North Florida Research and Education Center-Monticello (NFREC). It produces a large, purple grape that is somewhat more elongated and much sweeter than 'Jumbo'.

'Fry': Perhaps the most popular muscadine grape cultivar. It is a pistillate cultivar and produces a very large, bronze grape. Yield, vigor, and disease resistance are moderate. The period from first ripening to last ripening can extend to 6 weeks.

'Granny Val': A self-fertile cultivar that produces an extremely heavy yield and extends the harvest season into 
late September and October (Figure 2). In some years, it can overproduce and stress the vine. Berries are bronze but are not quite as large or sweet as Fry. Cordon dieback has been a problem. Due to a tendency to overcrop, 'Granny Val' should be pruned to two node spurs.

'Ison': A self-fertile cultivar that produces a moderate to large, black grape. Yields are said to be high. It may be a good choice as a pollenizer. Harvest season is early and vine vigor is high.

'Pam': A pistillate cultivar that produces a very large, yellowish-bronze grape with a mild muscadine flavor. It has a good flavor and is attractive. Yield is moderate and vine vigor is high. Harvest is midseason.

'Pineapple': A self-fertile cultivar that produces a mediumlarge, bronze grape. Vine vigor and yield are moderate and harvest season is mid- to late-season. It may have a tendency to overcrop. It is reported to have a pineapple flavor, although that was not detectable by the author.

'Polyanna': A self-fertile cultivar that produces a mediumlarge, dark purple grape. It is not patented. Yields have been rated moderate to high. Berry flavor is very sweet and berries are attractive. Vigor is medium-high and harvest season is medium to late. 'Polyanna' has potential as a pollenizer for pistillate cultivars.

'Southern Home': An interspecific $V$. rotundifolia $\times V$. vinifera that has considerable ornamental value owing to a bilaterally convex leaf with deeply cut sinuses (Figure 3). It produces a black berry with a cluster size of about 12. Berry size is medium, and berry flavor is nonmuscadine. Yield is moderate to high, and its ripening period is from August to November.

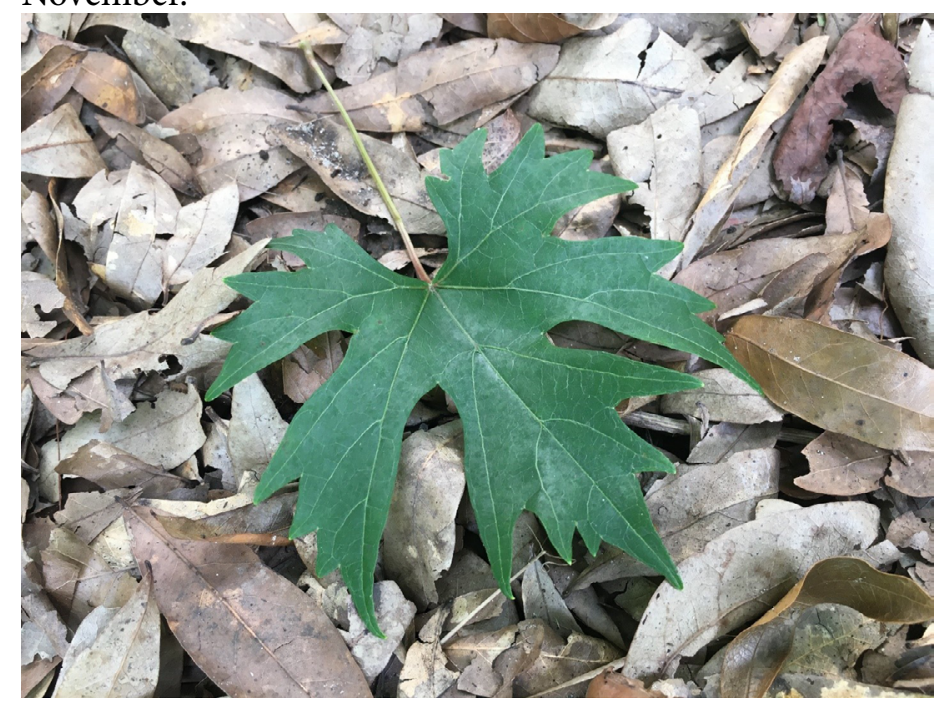

Figure 3. Unique leaf shape of 'Southern Home'. Credits: Dustin Huff, UF/IFAS
'Summit': An excellent fresh-market bronze cultivar. It is not patented. It is a pistillate cultivar that produces a very sweet, medium-large grape. Vigor is high, and yield is moderate to high. Yields and disease resistance are higher than those for Fry, although berry size is slightly smaller. It has a midharvest season.

'Supreme': A pistillate cultivar that produces a very large, very sweet dark purple grape (Figure 4). Yields have been high in southern Georgia. It is low in vigor, and vine mortality may occur if vines are allowed to overproduce. Vines should be pruned to 2 node spurs to avoid overcropping. Harvest is mid- to late-season.

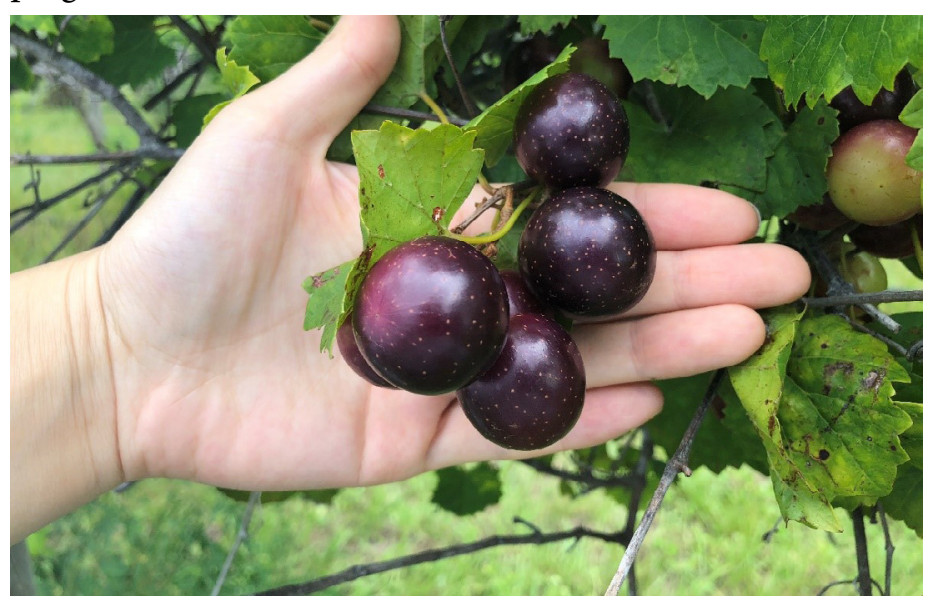

Figure 4. 'Supreme' berries.

Credits: Ali Sarkhosh, UF/IFAS

'Sweet Jenny': A pistillate cultivar that produces a very large, bronze grape early in the season. Vine vigor and yield are moderate. Disease resistance has been reported to be low to moderate, and berry blemishes are more apparent than on other cultivars.

'Tara': A self-fertile cultivar that produces a large, bronze grape. It is not patented. Vine vigor and yield are moderate. It has an early- to midseason harvest. 'Tara' has potential as a pollenizer for pistillate cultivars.

'Triumph': A self-fertile bronze grape with a pink hue. Vine yields are consistently high and produce medium-large berries in the early season (Figure 5).
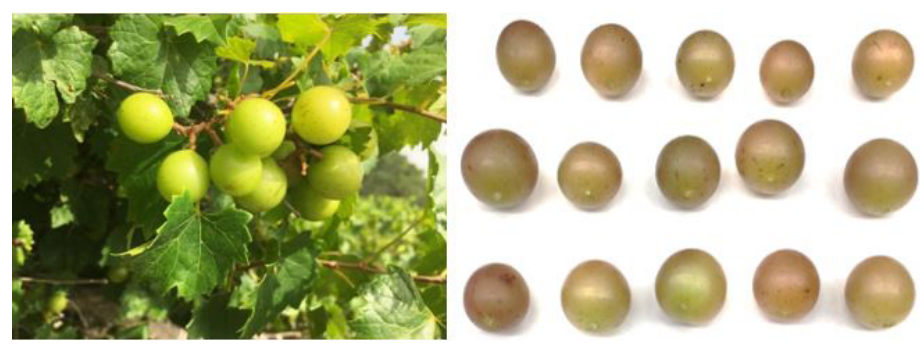

Figure 5. 'Triumph' berries before veraison (change of color) (left) and at ripe stage (right).

Credits: Dustin Huff, UF/IFAS 


\section{Recommended Cultivars for Processing into Wine, Juice, and Jellies}

'Alachua': It produces a medium-sized black berry. It is not patented. Vines are self-fertile, productive, and medium-high in vigor (Figure 6). Berries ripen uniformly in midseason. The fresh-market potential of 'Alachua' is limited due to lack of a competitively sized berry.

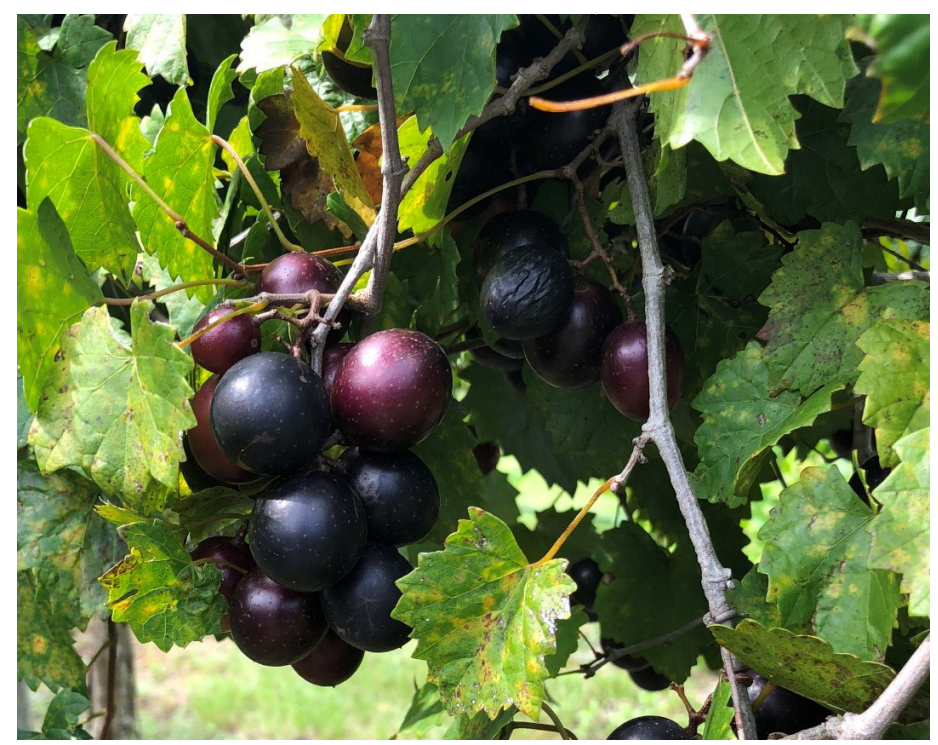

Figure 6. 'Alachua' berries.

Credits: Ali Sarkhosh, UF/IFAS

'Carlos': It is an extremely heavy producer of mediumsized, bronze grapes. It is self-fertile and will provide the tonnage and quality required for juice or wine production (Figure 7). 'Carlos' is the number-one bronze juice or muscadine wine grape in the southeastern United States. In years of heavy production, drought, or mineral stress, it has shown symptoms of Pierce's disease.

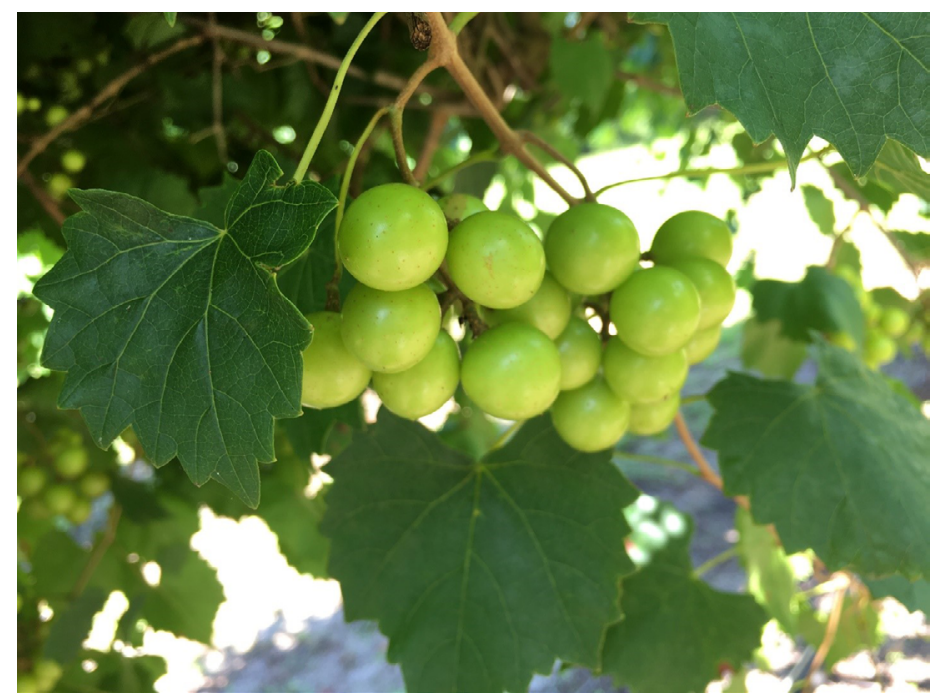

Figure 7. 'Carlos' berries before veraison. Credits: Dustin Huff, UF/IFAS

'Noble': The most popular red muscadine grape for wine or juice production. It is self-fertile and not patented
(Figure 8). Yields and disease resistance are high, and berry ripening is fairly uniform. Flavor is less musky than most muscadine grapes. 'Noble' has color stability and is a good wine grape.

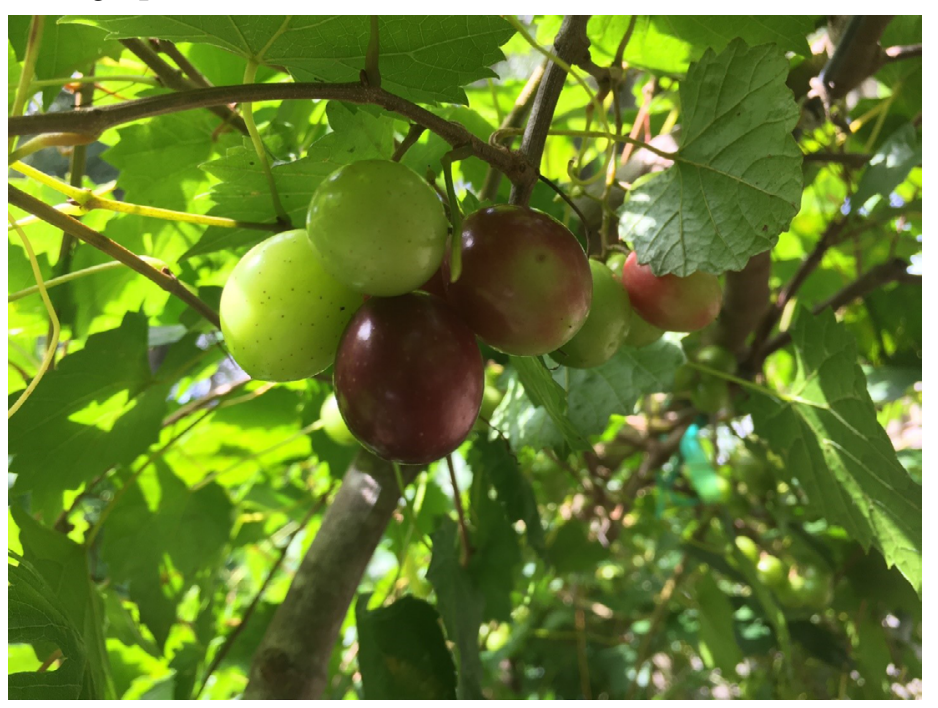

Figure 8. 'Noble' berries at veraison.

Credits: Dustin Huff, UF/IFAS

'Welder': It is a nonpatented, bronze grape that produces a good juice or wine. Yield is moderate, and the berry ripening period can be very extended such that three harvests may be required.

\section{Fresh-Market Cultivars Recommended for Trial}

'African Queen': A pistillate cultivar that produces a large, black grape. Quantitative yield data are lacking for Florida, although yield has been erratic in southern Georgia. It ripens midseason.

'Big Red': A pistillate cultivar that produces a very large, red grape. Quantitative yield data are lacking for Florida, although yields have been erratic in southern Georgia. Vigor is very low. It ripens mid- to late-season.

'Creek': 'Creek' produces a small, purple berry that is higher in acid than most muscadine grape cultivars. It is not patented. Vine vigor and yield are moderately high and ripening season is late. Color stability for juice or wine has not been tested to our knowledge.

'Darlene': A pistillate cultivar that produces a very large, pink grape. It ripens early to midseason, and vine vigor is high. Quantitative yield data are lacking for Florida, although yields have been erratic in southern Georgia.

'Delicious': A self-fertile, bronze-fruited cultivar that is sweet and medium-large in size. It is not patented. It also 
has attributes of even ripening and a dry scar. 'Delicious' is a good candidate for mechanical harvesting. 'Delicious' has not been evaluated at the NFREC-Quincy.

'Doreen': A self-fertile cultivar that produces a large crop of small to medium-sized berries. It is not patented. Harvest season is late. Quantitative yield data are lacking for north Florida. Doreen is reported to be one of the best cultivars for juice production.

'Early Fry': This cultivar resembles 'Fry' but ripens earlier. It is a pistillate cultivar that produces a dark bronze fruit. Vine vigor and yield were rated low in north Florida, although yield estimates appear high in southern Georgia.

'Eudora': A pistillate cultivar that produces medium-large, sweet, purple-colored fruit. It is not patented. Although it has an uneven ripening period, berries within a cluster ripen uniformly, thus allowing for the harvest of entire grape clusters. 'Eudora' has not been tested at the NFREC-Quincy.

'Florida Fry': A self-fertile cultivar that produces a medium-large, sweet bronze grape. Harvest season is midto late-season. Vine vigor is moderate. Yield is expected to be moderate to high, but quantitative yield data are lacking.

'Golden Isles': It is a nonpatented, self-fertile cultivar that ripens midseason. Berries are small to medium in size, and taste is nonmuscadine for a muscadine grape. Quantitative yield data have not been collected for Florida.

'Majesty': A pistillate cultivar that produces large, moderately sweet, purple-colored berries. It is patented. Vine vigor and yield is reported to be high, although 'Majesty' has not been tested at the NFREC-Quincy.

'Nesbitt': This cultivar produces a self-fertile black grape that is medium-large in size. It is not patented. Yields are high and crop is mid- to late-season. This is a multiuse grape for fresh market or processing.

'Southern Jewel': A self-fertile vine that produces a large, black-colored fruit moderately high in soluble solids. It is not patented. It has been reported to be high yielding and disease resistant, although it has not been evaluated at the NFREC-Quincy.

\section{Propagation}

In the wild, muscadine grapes are propagated sexually from seed and asexually by a natural tendency of shoots to form roots when they make contact with the ground.
Muscadine grapes are very easy to propagate asexually. Asexual propagation produces a plant that is genetically identical to the mother plant. Propagation from seed will produce plants that vary genetically and that are not true to type. The most common propagation method is to make 2 - to 3 -node-long cuttings from shoots $1 / 4$ to $3 / 8$ inches in diameter in June or July (Figure 9). Simply insert the basal end of the cutting in a light-textured soil or potting media. Keep the roots and leaves moist until roots have formed (usually about 2 weeks). A mist bed can be inexpensively constructed for this purpose. The buds in the leaf axils will break and form shoots shortly thereafter. Dipping the basal ends of the cuttings in Rootone ${ }^{\circledR}$ or other formulations of napthelene acetic acid can enhance rooting percentages but is not required.

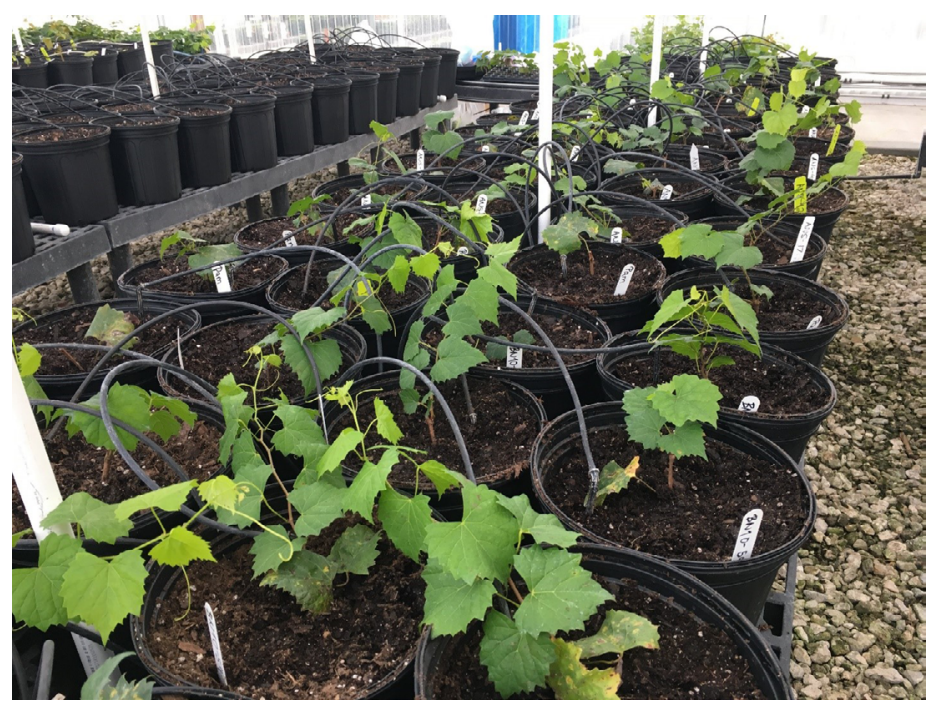

Figure 9. Greenhouse propagation of muscadine vine using softwood cutting in June.

Credits: Dustin Huff, UF/IFAS

Another method to asexually propagate muscadine grapes is called pegging (Figure 10). To use this method, wound a low-growing shoot by making successive cuts in the bark, and then cover it with moist soil. Leave the shoot tip exposed. After about a month, roots should have formed, and the shoot may be severed from the mother vine. Pegging can be done in the summer months and is most useful to propagate a few vines. For mass propagation, stem cuttings are preferable. Virtually hundreds of cuttings can be rooted from a single mother vine.

\section{Planting}

Muscadine grapes are adapted to a wide range of soil conditions. Ideal soils are loamy sands and sandy loams; although clay soils and sandy soils are also satisfactory with proper irrigation and drainage inputs in sandy soils, muscadine grapes will require more frequent irrigation because of the reduced water-holding capacity of the soil. Low-lying areas 
should be avoided because they are associated with poor air circulation and water drainage that contribute to increased probability of frost injury and waterlogging, respectively. The most critical elements to success of newly planted and young vines are irrigation and weed control. Bare-root vines should be planted December through February, whereas container-grown vines can be planted throughout the year, provided that they receive adequate irrigation.

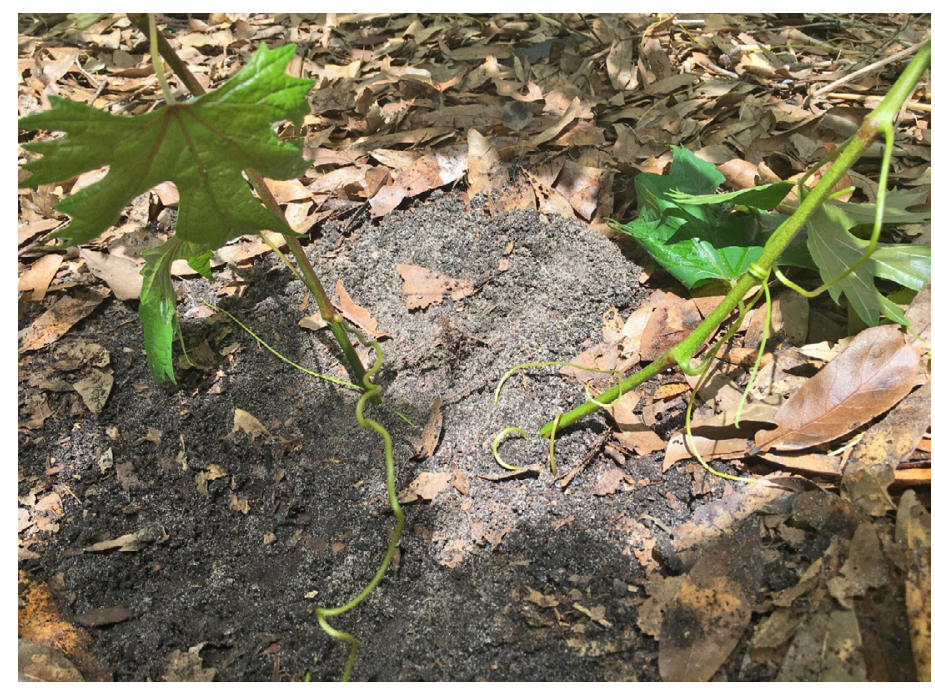

Figure 10. Pegging propagation of muscadine vine. Credits: Dustin Huff, UF/IFAS

A hole should be dug to accommodate the entire root system, usually about 2 feet deep and 2 feet wide. Commercial growers often subsoil to a depth of 1 to 2 feet prior to setting the posts. Several nursery growers recommend planting muscadine roots in 3-foot-long, 1-foot-deep trenches. In the case of extremely long roots, it is probably preferable to cut them rather than have them circled around extensively in the planting hole. Planting distances and configurations are dependent on vineyard design.

\section{Vineyard Design}

Muscadine grapes can also be planted in an arbor configuration for home fruit production, or in a traditional post-and-wire configuration. A multitude of customized designs can be employed for an overhead arbor, typically with a 7- to 10-foot height requirement. The arbor can include sides. Archways can also be included. Muscadine grapes are fast growers, and after only three years, a grape can easily cover a 6 -foot by 15 -foot horizontal area. Several cultivars could be planted together to enhance the duration of the ripening period and also to provide a variety of grape sizes, colors, and flavors.

The three most common vineyard designs are 1) a singlewire design for vines destined to be trained to a bilateral training system 5 to 6 feet above the ground; 2) a two-wire vertical design with two wires at a height of approximately 3 and 6 feet; and 3) a two-wire horizontal design whereby vines are trained to two wires two feet to either side of the post at a height of about 5 to 6 feet. This last system is known as a Geneva double curtain system. Plant spacing is dependent on vineyard design but is typically 12 to 20 feet within a row and 10 to 15 feet between a row for bilateral cordon training and two-wire vertical training systems. For vineyards destined to be a Geneva double curtain, the minimum between-row spacing is 12 feet, but 14 to 15 feet may be more practical for use of standard farm machinery. The most efficient distance between posts located within a row is about 15 to 20 feet. Establishment costs increase below this post density, and above 20 feet there is too much sagging in the wire. Plant and post density should be the same, and it is advisable to plant vines one to three feet away from each post to further minimize wire sagging.

End posts should be 10 feet long and at least 6 to 7 inches in diameter. In-row posts should be a minimum of 8 feet in length and at least 4 to 5 inches in diameter. In-row posts should be planted two feet in the ground, while end posts should be planted to a depth of 3 to 4 feet. End posts should be slanted at an angle of 15 to 30 degrees from the vertical away from the vineyard and supported with heavy-duty screw anchors or dead man anchors. Smooth galvanized number 9 wire should be used. Row length should not exceed 600 feet due to maximum load requirements and stretching of the wire. Sixteen-to-24-inch turnbuckles can be placed at various locations to take up wire slack as it occurs over time. This may be preferable to removing and stretching wire every several years. Heavy-duty wire staples can secure the wire to the top or the sides of the posts. Grounding rods should ground the wire every 100 feet to minimize losses due to lightning strikes. Otherwise the lightning bolt can travel along the entire wire, potentially killing every vine in the row. The three training systems will next be discussed in more detail.

The simplest training system to establish and maintain is the single-wire bilateral cordon training system (Figure 11). After planting, a single vertical shoot is trained to the wire. Normally at least 3 or 4 competing shoots will emerge from the young plant. Simply select the strongest and straightest. The upward growth of the shoot is supported by a stake or string attached to the wire (Figure 12). Prune off side-shoots as they emerge (Figure 13), but do not remove the leaves growing directly on the trunk. During the early summer, the shoot should reach the 5- to 6-foot wire. Promote the formation of straight shoots, since the shoot will harden and become inflexible as it matures. As 
it reaches the wire, prune the tip of the shoot to facilitate the growth of two side branches to either side of the wire. The upward-growing shoot will become the trunk, and the shoots growing along the wire will become the cordon. Cordon establishment should be completed during the first growing season. Be sure to remove the string from the trunk or any tags that may girdle the vine. Keep lateral shoots no longer than 1 foot from the cordon to ensure that enough growth goes into cordon formation (Figure 14).

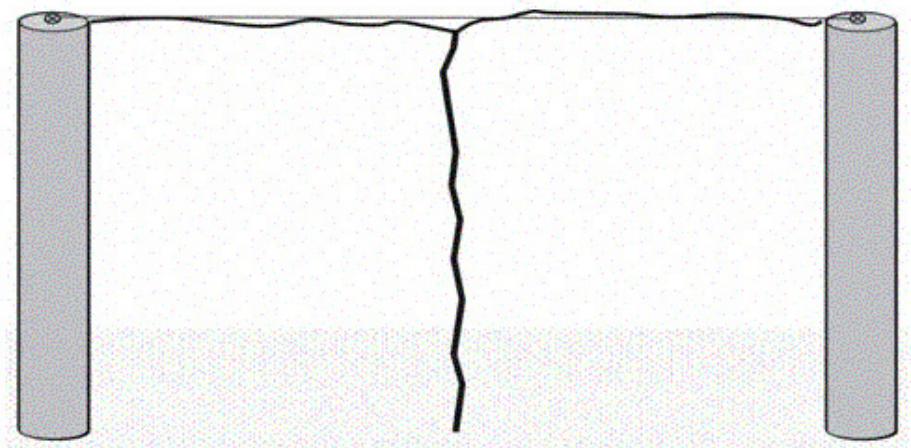

Figure 11. Bilateral cordon training system.

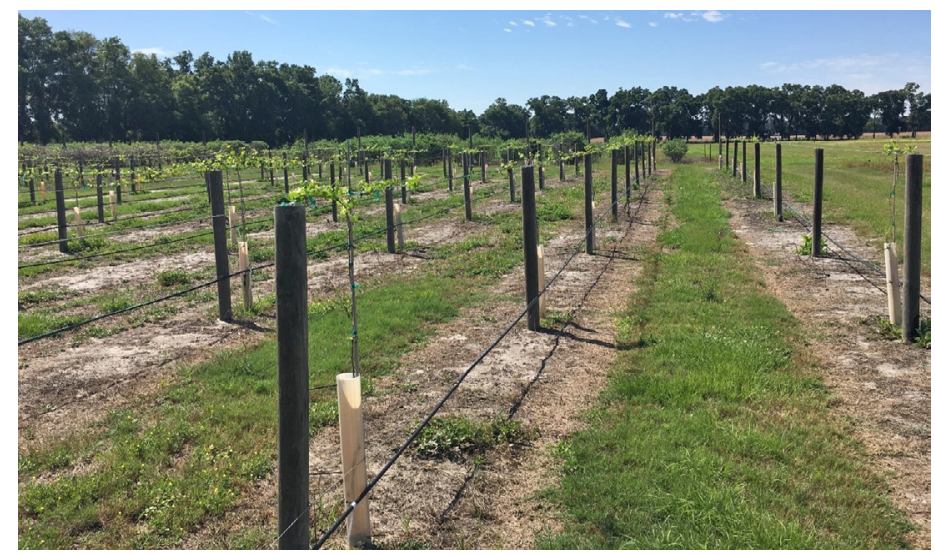

Figure 12. Training of young muscadine vines.

Credits: Dustin Huff, UF/IFAS

A two-wire vertical system (Figure 15) was common about $20-40$ years ago but has declined somewhat in popularity because of higher maintenance costs and the extreme difficulty in controlling weeds. With multiple rows, shading is excessive on the lower cordon. Two wires are placed along posts at heights of 3 and 6 feet. Training is similar to the previous method except that the lateral shoots are encouraged and selected at the 3-foot height in addition to the top wire. This system will provide twice the cordon fruiting area as the bilateral cordon method, but cordon maintenance on the lower cordon is a job that requires hands-and-knees labor.

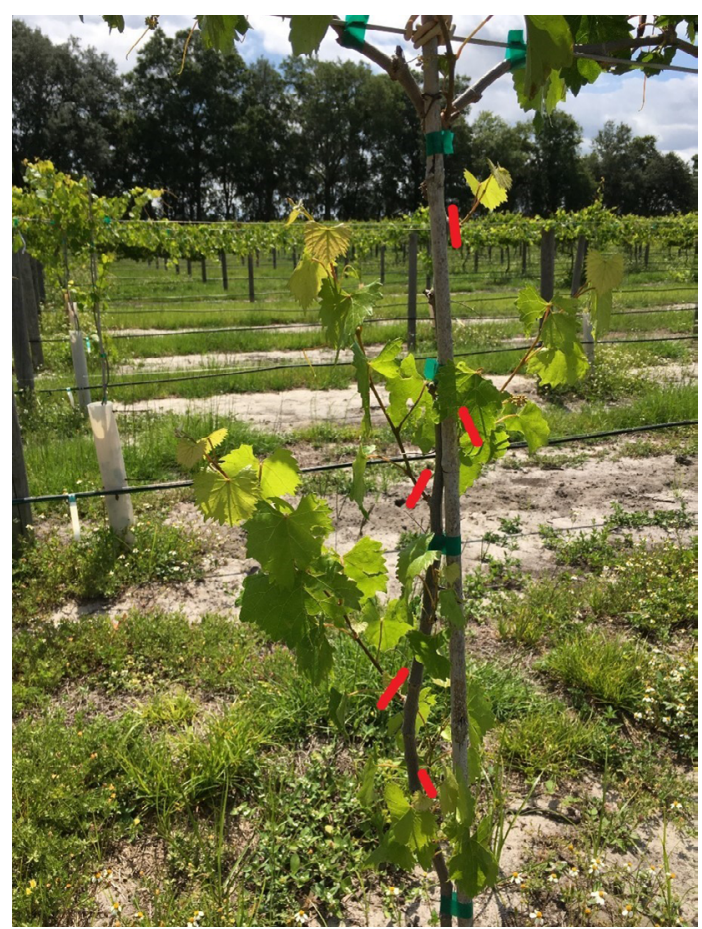

Figure 13. Remove side shoots of the main trunk (indicated by red lines). Photo

Credits: Dustin Huff, UF/IFAS

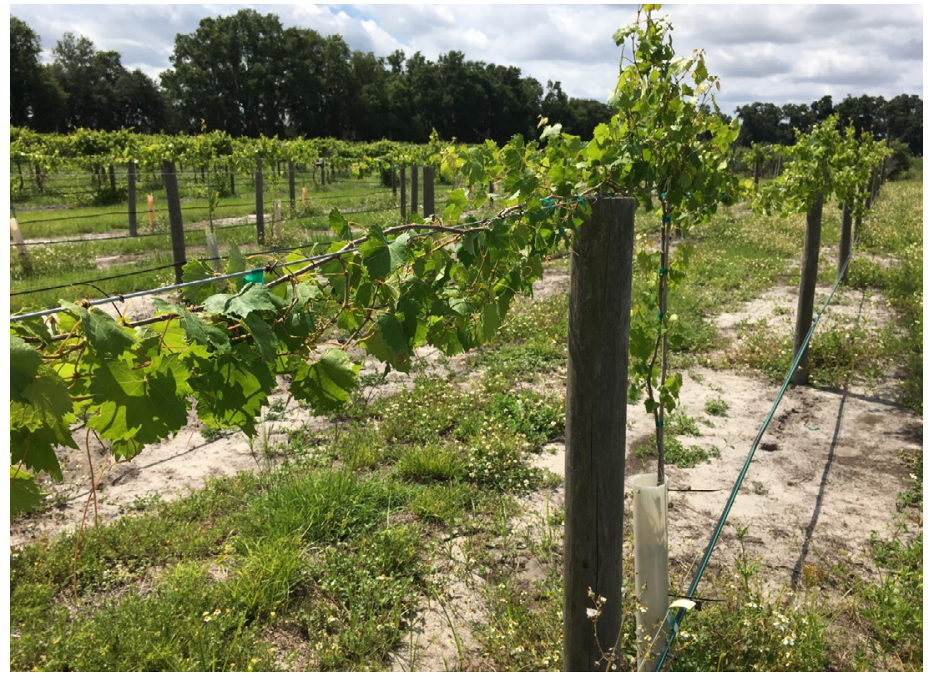

Figure 14. One-year-old trained muscadine vine.

Credits: Dustin Huff, UF/IFAS

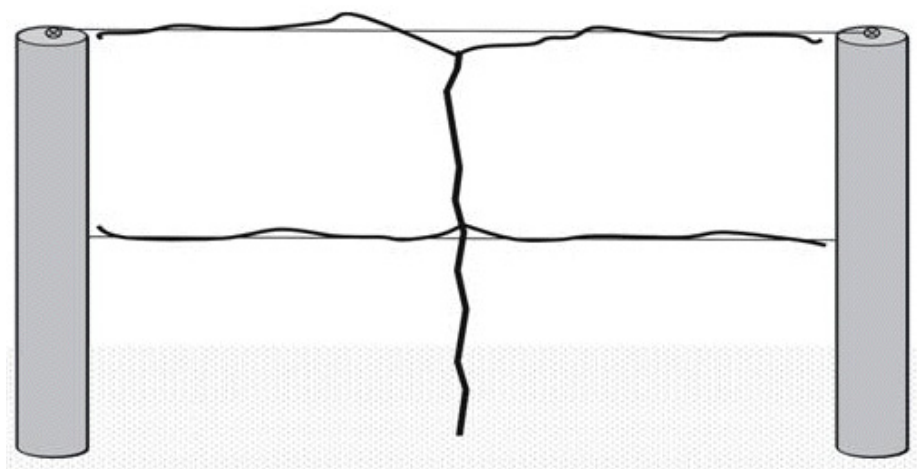

Figure 15. Two-wire vertical training system. 
The Geneva double curtain system (Figure 16) was designed to maximize light interception per acre, particularly in northern grape-growing regions. A V-shaped support system is established about 4 feet above the ground, and a wire traverses the top of each arm of the $\mathrm{V}$ at about 5 feet. The top of the V should be about 3 to $3 \frac{1}{2}$ feet across. The $\mathrm{V}$ can be constructed out of metal or a pressure-treated $2 \times 4$ and fastened to the post with bolts and/or lag screws. Historically, wooden-based structures have only lasted about 5 to 10 years due to wood decay and the strain associated with high crop loads. Metal V frames can be manufactured with a longer life expectancy. The vine is trained to the center wire as indicated for the bilateral cordon training system; however, the vine is encouraged to produce lateral shoots directed toward the top of each V. At that point, the shoot can once again be pinched to encourage lateral branches along the wires located at the top of the V.

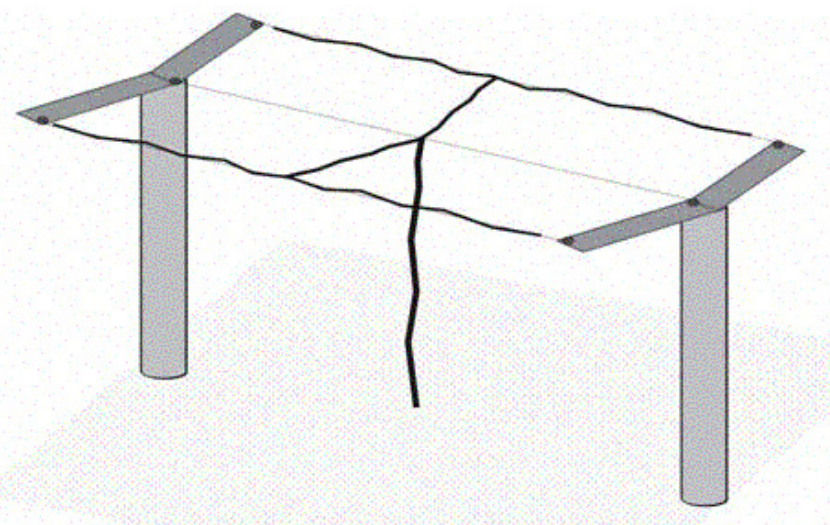

Figure 16. Geneva double curtain training system.

The advantages of the Geneva double curtain training system are high per-acre yields and good berry quality, and the avoidance of problems associated with maintaining a lower wire. Disadvantages are higher maintenance costs. Thinning shoots in the head region can be especially troublesome. Long-term yield for 31 cultivars in one study (Andersen et al. 1985) and 23 cultivars in another have produced the following average yields results: Geneva double curtain, 6.4 tons/acre; two-wire vertical, 5.5 tons/acre; and bilateral cordon, 4.5 tons/acre. Regardless of training system, self-fruitful vines often tend to outproduce pistillate cultivars. Pruning and harvesting is much easier with the bilateral cordon training system. In reality, economic return per dollar invested may be highest for a bilateral cordon training system, especially over the long term. For much of the muscadine growing region, land costs are not particularly high, which is another reason why maximizing yield per acre is not overly critical. Yield per dollar invested is a more critical determinant.

\section{Pruning}

The shoots of muscadine grapes arise from buds in the leaf axils of the past season's growth. The fruit of muscadine grapes is borne in 6- to 12-berry clusters on the current year's growth. Flowers appear after several weeks of shoot growth, usually in April. Muscadine grapes seldom sustain frost injury in the spring due to the late bloom date. Certain cultivars are susceptible to winter injury, especially if a drastic decline in temperature occurs before the vine is acclimated to minimum winter temperatures. Pruning in November or December can exacerbate the degree of winter injury. For this reason, the best time to prune is mid-January to mid-March (Figure 17). When acclimated, most vines can tolerate temperatures down to about $10^{\circ} \mathrm{F}$ without injury.

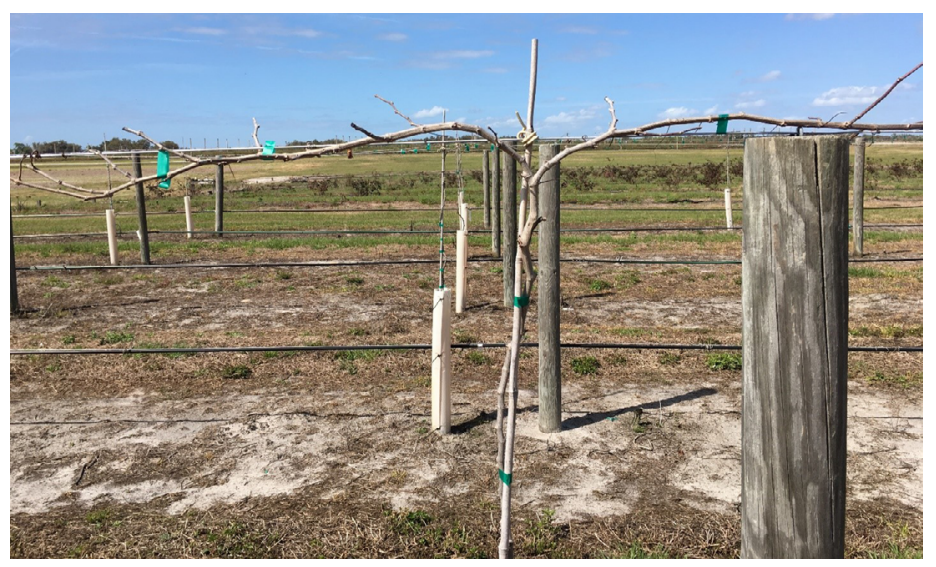

Figure 17. One-year-old trained vine after completion of first winter pruning.

Credits: Dustin Huff, UF/IFAS

After a grapevine has been trained to a desired configuration, it must be pruned to keep it manageable and to ensure maximum vine performance. As indicated above, major pruning is normally done during the dormant season, although touch-up pruning can be done during the growing season. Earlier pruning can sometimes enhance winter injury. You may notice that pruning cuts bleed when soil temperatures are high, but there is no evidence that this is injurious to the vine. In addition, it is necessary to remove shoots that grow within $2 \frac{1}{2}$ feet of the ground prior to herbicide application. The standard rule is to allow 2 to 4 node spurs spaced about every 6 inches of cordon. This will allow approximately 120 nodes per bilateral cordon-pruned vine at a 16 -foot spacing. For a heavy-yielding vine such as 'Carlos' or 'Noble', it is not uncommon to achieve an average sustained yield of 8 tons/acre, which translates to about $60 \mathrm{lb} /$ vine at a 10-by-16-foot spacing within and between rows, respectively. A problem invariably encountered over time is that the new nodes that are selected each successive year are located farther and farther from the cordon. Nodes that emanate on spur locations that are too far from the 
cordon eventually lose productivity and also result in a vine that is more difficult to manage. Under these situations, spur renewal is recommended every 3 to 6 years so that new fruiting wood never arises more than a foot from the cordon. Spur thinning can be accomplished by removing entire spurs or part of them. After 5 to 10 years, it is not uncommon for cordons to lose vigor or die from disease or winter injury. Simply select another young shoot to train along the wire. It will become your cordon the following year.

In order for muscadine juice or wine grapes to be profitable, mechanized pruning and harvesting is essential. Mechanized pruning can take place with a gas-powered hedge trimmer or chain saw. On a larger scale, sickle bars can be mounted to a tractor in both horizontal and vertical orientations so that all shoot growth more than 8 to 12 inches from the cordons is removed. Mechanized pruning saves a tremendous amount of pruning labor; however, every second or third year it should be followed by touch-up hand pruning (Figure 18). In a 6-year study, 'Noble' muscadine grapes subjected to mechanized pruning displayed a linear reduction in yield and total soluble solids, indicating that vines needed to be reinvigorated by touchup hand pruning and spur renewal. Severe hand pruning in alternate years induced alternate bearing where high and low yields were recorded in successive years.

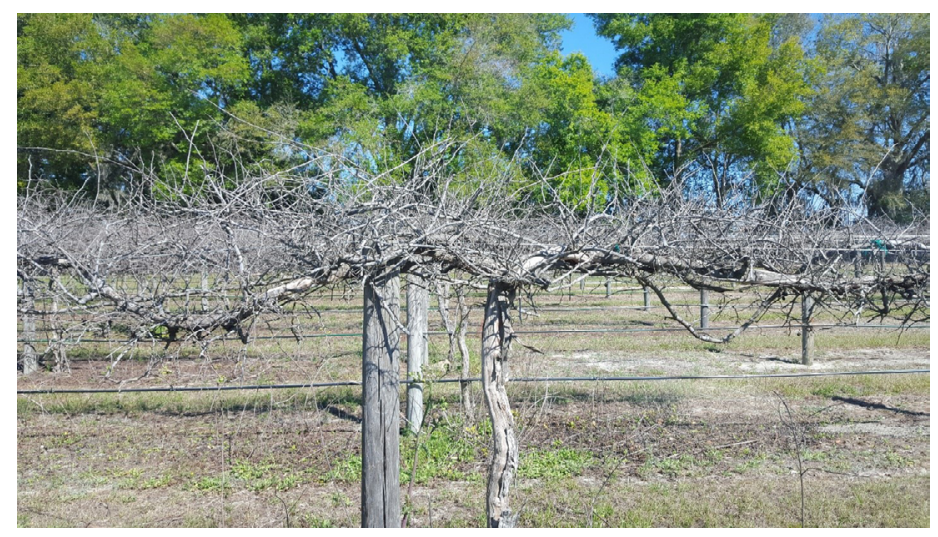

Figure 18. Mature vine hedged, some spur thinning and shortening still needed.

Credits: Dustin Huff, UF/IFAS

\section{Irrigation}

Irrigation is essential during the entire establishment year for muscadine grapes. Irrigation will also be beneficial for fruiting vines. The most critical period for irrigation is May through June. After this time, the quantity of summer rainfall is usually sufficient to meet the vine needs. Drip irrigation is the most efficient form of irrigation (Figure 19). During the first year, one emitter placed within 1 foot of the vine is sufficient. Two additional emitters can be placed about 3 feet to either side of the vine for subsequent years. This is especially advisable for sandy soils where water-holding capacity and the quantity of soil volume is limited. One- or 2-gallon-per-hour emitters are satisfactory. During dry periods, two gallons per emitter per day $(2$ gallons per vine) is satisfactory the first year, while 4 gallons per emitter per day (12 gallons per vine) is satisfactory for subsequent years. Irrigation to bearing vines should be limited in August and September to facilitate berry ripening and sugar accumulation.

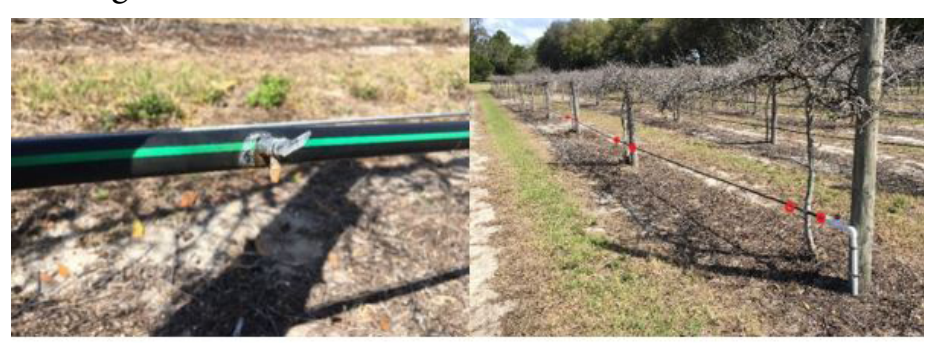

Figure 19. Close-up of irrigation dripper (left). Red circles depict placement of drippers on the irrigation line in older vines (right). Credits: Dustin Huff, UF/IFAS

\section{Fertilization}

Prior to planting, determine soil $\mathrm{pH}$ and soil nutrient status. Soil $\mathrm{pH}$ should be in the range of 5.5 to 6.5. To increase the $\mathrm{pH}$ by 1 unit, mix about $5 \mathrm{lb}$ lime per 100 square feet of soil. To decrease $\mathrm{pH}$ by 1 unit, add $1 \mathrm{lb}$ elemental sulfur per 100 square feet of soil. Fertilize each plant with 1/4 lb 8-8-8 or 10-10-10 in April after growth begins. Apply the fertilizer in bands about 1 foot to either side of the vine. It is sometimes beneficial to apply fertilizer that has micronutrients added. Repeat this process in June and in August. During the second year, apply 1 to $2 \mathrm{lb}$ of fertilizer per vine in March and again in June/July. In future years, the fertilization rates can be 3 to $4 \mathrm{lb}$ of fertilizer per vine during March and June/July.

\section{Weed Control}

In Florida, weed control is an extremely critical vineyard operation. A 5-to-6-foot-wide, in-row strip should be maintained free of weeds. Check with your county Extension office each year to obtain a list of herbicides labeled for muscadine vineyards. Pesticide recommendations change each year as labels change and pesticides are removed and added to the agricultural marketplace. It is essential to check yearly to make sure your herbicides are the most effective available. Alternatively, in small vineyards, weeds can be manually controlled. Remember that the roots of muscadine grapevines are shallow, and deep cultivation can injure root systems. Weed control is not only beneficial to vine growth and vine productivity, but it also facilitates all vineyard operations. 


\section{Insect Control}

Muscadine grapevines are tolerant of most insect pests, and seldom are insecticides warranted. Periodically, aphid outbreaks may occur on shoot terminals, but they seldom persist more than a few weeks due to the work of natural enemies (Figure 20). Chilli thrips (Scirtothrips dorsalis) can also cause significant economic damage if not controlled (Figure 21). The grape root borer (Vitacea polistiformis) is thought to be a significant pest of muscadine grapevine and may contribute to vine mortality, but good data on its economic impact are lacking. The adult is a moth that resembles a wasp and emerges and lays its eggs at a time of the year dependent on latitude. The larvae bore into roots at the base of the trunks and damage vines by consuming root tissue. An in-row strip maintained weed-free by the use of herbicide is thought to minimize the density of grape root borers in the root. Also, a soil insecticide can be used to control this pest. Monitor and watch for the emergence of the adult insects so that you can time the application of insecticide. For more information, refer to Insect Management in Grapes (https://ufdc.ufl.edu/IR00005826/00001).

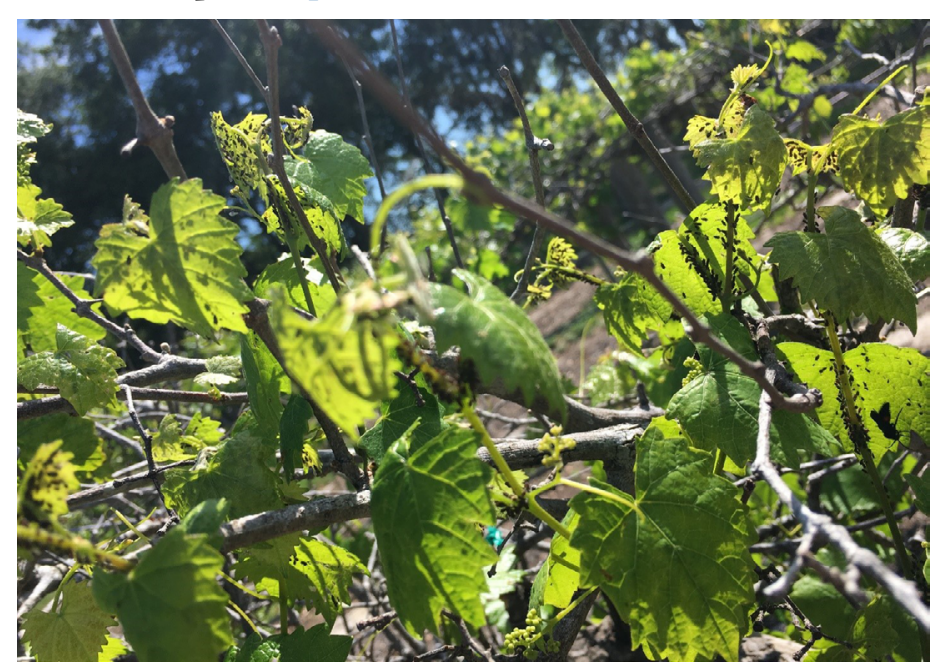

Figure 20. Aphids on early spring growth.

Credits: Dustin Huff, UF/IFAS

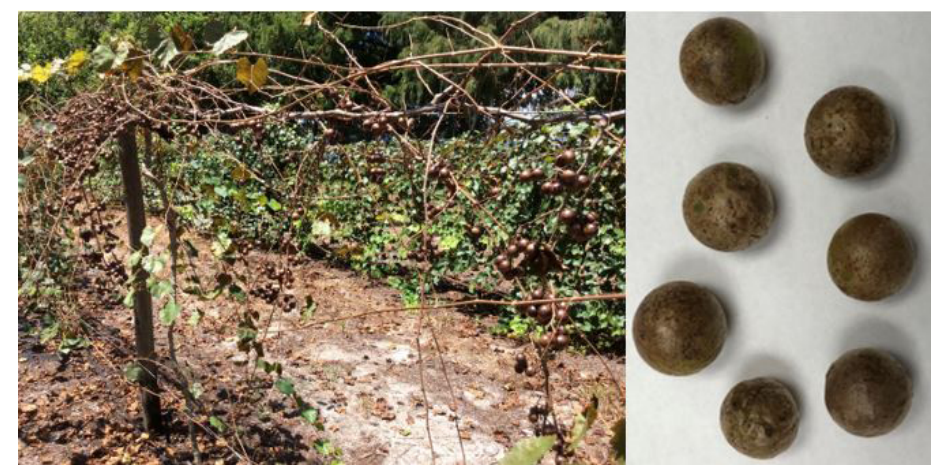

Figure 21. Muscadine vines (left) and berries (right) damaged by chilli thrips in central Florida.

Credits: Ali Sarkhosh, UF/IFAS

\section{Other Animal Pests}

A multitude of animal pests consume muscadine grapes, including raccoons, squirrels, crows, opossums, coyote, and deer. Moderate to large vineyards can outstrip the ability of animal pests to drastically reduce production; however, small vineyards, particularly when adjacent to woodlands or other good wildlife habitat, can be severely impacted. For this reason, and the fact that muscadine grapes perform well only in full sun, vineyard locations should be away from woodlands as much as possible.

\section{Diseases}

Muscadine grapes are one of the fruit crops grown in Florida that is considered a sustainable crop, and many cultivars can be grown completely without pesticides. Some of both the established and recent cultivars are not quite as disease-resistant, so if you are establishing a new vineyard with organic growing in mind, be cognizant of the different levels of disease resistance. Also, if blemish-free berries are desired for fresh-market sales in grocery stores, then it may be advisable to spray fungicides.

There are many cultural practices that can minimize the incidence of grape diseases. First and foremost, plant disease-resistant cultivars (see Table 4). Second, choose training systems and use maintenance practices that confer good air circulation. Bilateral cordon systems are much better than Geneva double curtain or two-wire vertical training systems at facilitating air movement through a canopy, and maintaining a clean vineyard floor under the vines also promotes beneficial movement of air. Third, avoid irrigation systems that wet the foliage: instead of overhead systems, use drip or microjet irrigation. Fourth, pick the grape berries at harvest time and remove mummified berries, dead wood, and pruned wood from the vineyard.

The most common diseases on muscadine grape berries and/or leaves are angular leaf spot, black rot, ripe rot, macrophoma rot, and powdery mildew. Bitter rot can infect all aboveground tissue. Black rot and powdery mildew are cool-weather diseases and are easy to control. Bitter rot, macrophoma rot, and ripe rot are diseases that occur toward berry maturity, and they are more problematic. Anthracnose is a common disease of bunch grapes and is a dominant factor precluding the culture of most bunch grape cultivars; however, it is not a major problem on muscadine grapes. A brief description of the diseases will follow. Positive diagnosis can be accomplished by any of the statewide UF/IFAS Plant Diagnostic Laboratories. 


\section{Angular Leaf Spot}

Angular leaf spot (Mycosphaerella angulata) is a disease that only attacks the foliage and may cause premature leaf drop. This disease appears as angular, dark brown spots surrounded by a halo. Premature leaf loss can result in increased levels of vine stress that may reduce fruit quality and vine longevity.

\section{Bitter Rot}

Bitter rot is fairly common and is primarily a berry disease. It is caused by the fungus Melanconium fuligineum. Mature fruit are most susceptible, and fruit characteristically have a bitter taste. Symptoms are a bleached, water-soaked spot that eventually expands to encompass the entire berry. It typically begins at the pedicel, or the fruit attachment point. The fruit eventually becomes dry, mummified, and dark in color. Bitter rot may also infect leaves, tendrils, and shoots, where it overwinters as lesions. It is difficult to control.

\section{Black Rot}

Black rot is mainly a disease of immature berries, young canes, and leaves. It is caused by the fungus Guignardia bidwellii. On fruit, black rot appears as dry, black, scabby spots. It can cause mummification and fruit drop. Leaf infection initially appears as light reddish-brown spots that expand to $1 / 4$ inch and turn light brown. Black rot overwinters on infected canes. It is much more of a problem on bunch grapes than on muscadine grapes.

\section{Macrophoma Rot}

Macrophoma rot is caused by Botryosphaeria dothidea, which is a difficult-to-control fungus with an extremely broad host range. Macrophoma rot overwinters on wood of numerous host plants and on the remains of infected berries. When it occurs, it usually appears close to berry maturity. This disease progresses rapidly and is particularly severe on the 'Fry' cultivar. Macrophoma rot begins as a small, light brown spot that becomes water soaked and consumes the entire berry.

\section{Powdery Mildew}

Powdery mildew is caused by the fungus Uncinula necator. It is a rather unmistakable fungus that is identified by an off-white, powdery growth on the plant surface. It strikes in dry, cool to warm weather. It is not a hot-weather disease. On leaves, a powdery mildew infection is seldom serious. On fruit, it may reduce berry size and induce fruit drop. Infected berries may exhibit brown scarring and may crack. Chemical control is normally not warranted.

\section{Ripe Rot}

Ripe rot is induced by the fungus Glomerella cingulata. Ripe rot is a disease of mature berries and spreads very quickly. It is particularly severe on 'Fry'. Spore-producing bodies on the berry skin give infected bronze berries a rusty appearance; this disease is more difficult to spot on red- or black-skinned berries. The berries eventually decay and become mummified. The disease overwinters on mummified berries.

\section{Harvesting}

Harvest is as early as late July for some cultivars and extends to late September for others. Typically, at least two harvests are required, but cultivars such as 'Fry' or 'Welder' may require up to five harvests. Harvesting can be accomplished by selecting individual grapes or bunches of grapes by hand, by shaking berries loose from a vine into tarps positioned beneath the vine, or by using mechanical harvesters that rake and shake the berries loose. Fruit dropping on the ground should be avoided so as to minimize cross-contamination of decay and human pathogens. Harvesting by hand is a labor-intensive vineyard operation. A disadvantage to the quality and postharvest shelf life of muscadine grapes is that many cultivars tear at the point of pedicel attachment. Those with a dry stem scar are preferable. Fruit damage during harvest and attack by disease organisms can reduce quality quickly and substantially. Harvesting early or late in the day is a definite advantage in preserving fruit quality.

The most feasible method to pick juice or wine grapes on a moderate scale is to shake berries onto tarps. For large-scale operations, mechanical harvesting is worthy of investigation. The price of muscadine grapes is too low to justify hand harvesting juice and wine grapes on a commercial scale. Before embarking on a moderate- to large-scale muscadine juice or wine venture, it would be prudent to know your market potential and check on contracts with nearby processing plants. On a small scale, homeowners or hobbyists may hand pick if they wish. For juice or wine grapes, maintaining fruit integrity is not a major issue if fruit will be crushed in a few hours.

Muscadine grapes should be refrigerated after harvest and on the way to the market. Muscadine grapes can be stored with refrigeration for up to three weeks at $33^{\circ} \mathrm{F}$ if no wet scars are present. However, most fresh-market cultivars have a shelf life of about 1 week. Relative humidity should be kept high, but condensation should be avoided. Refrigeration can extend the marketing period of muscadine 
grapes, although the first large-fruited muscadine grapes bring the highest price.

Many growers allow people to pick their own grapes in the form of U-Pick operations. Berries marketed in this manner normally sell for a lower price than in the supermarket. In addition, the consumer is getting a fresh product. It is advisable to start small and expand in size with demand. Convenient access to a highway and proximity to a city or town is a prerequisite. U-Pick operations must be clean, and insurance risks to customers, such as snakes and wasps, must be minimized. Good weed control and closely cut grass are advisable.

\section{References}

Andersen, P. C. 1992. "Performance of Cultivars and Selections of Muscadine Grapes in North Florida." Fruit Varieties Journal 46 (4): 245-249.

Andersen, P. C. 2006. "The Performance of 20 Muscadine Grape Cultivars in North Florida." J. Amer. Pomol. Soc. 60 (3): 129-135.

Andersen, P. C., M. W. Bryan, and L. H. Baker. 1985. "Effect of Two Wire Vertical and Geneva Double Curtain Training Systems on Berry Quality and Yield of Muscadine Grapes." Proc. Fla. State Hort. Soc. 98:175-178.

Andersen, P. C., C. A. Sims, and J. M. Harrison. 1996. "Influence of Simulated Mechanized Pruning and Hand Pruning on Yield and Berry Composition of Vitis rotundifolia Noble and Welder." Am J. Enol. Vitic. 47 (3): 291-296.

Clark, J. R. 2001. "Evaluation of Muscadine Grape Cultivars for Productivity, Fruit Quality and Winter Hardiness in Arkansas, 1987-1998." Arkansas Agricultural Experiment Station Special Report 203.

Crocker, T. E., and J. A. Mortensen. 1994. The Muscadine Grape. HS763. Gainesville: University of Florida Institute of Food and Agricultural Sciences.

Dittmar, P. J., and J. G. Williamson. 2018. Weed Management in Grapes. HS91. Gainesville: University of Florida Institute of Food and Agricultural Sciences. https://edis.ifas. ufl.edu/wg018

Ellis, H. C., D. Horton, J. Dutcher, J. All, H. Scherm, and W. Copes. 1999. "Commercial Muscadine Grape Pest, Management Guide." Cooperative Extension Service, The University of Georgia, College of Agricultural and Environmental Sciences.
Hopkins, D. 1989. "Xylella fastidiosa: Xylem-Limited Bacterial Pathogen of Plants." Annual Review of Phytopathology 27 (1): 271-290.

Krewer, G., S. C. Myers, M. E. Ferree, R. Lane, D. Horton, P. Bertrand, and G. Westberry. 1994. "Commercial Muscadine Culture." Athens, GA: Cooperative Extension Service, The University of Georgia College of Agricultural and Environmental Sciences. 1-16.

Mortensen, J. A., and C.P. Andrews. 1981. "Symposium: Grapes in Florida Grape Cultivar Trials and Recommended Cultivars for Florida Viticulture." Proc. Fla. State Hort. Soc. 94:328-331.

Mortensen, J. A., and J. W. Harris. 1988. "Muscadine and Bunch Grape Fresh Fruit Taste Panels during 21 Years with 101 Cultivars." Proc. Fla. State Hort. Soc. 101:229-232.

Mortensen, J. A., and J. W. Harris. 1989. "Yields and Other Characteristics of Muscadine Grape Cultivars at Leesburg. Proc." Fla. State Hort. Soc. 102:223-226.

Olien, W. C. 1990a. "Muscadine Grape-A Classic Southeastern Fruit." HortScience 25 (7): 726, 831.

Olien, W. C. 1990b. "The Muscadine Grape: Botany, Viticulture, History, and Current Industry." HortScience 25 (7): 732-739.

Stoffella, P. J., J. A. Mortensen, N. C. Hayslip, and J. B. Brolmann. 1982. "Evaluation of Muscadine Grape Cultivars in South Florida." Proc. Fla. State Hort. Soc. 95:90-92.

Talcott, S. T., and J. H. Lee. 2002. "Ellagic Acid and Flavonoid Antioxidant Content of Muscadine Wine and Juice." Journal of Agricultural and Food Chemistry 50 (11): 3186-3192.

USDA-NASS. Census of Agriculture. 2017. https:// www.nass.usda.gov/Publications/AgCensus/2017/index. php\#full_report 
Table 1. Yield, berry weight, soluble solids, and berry number per cluster for two-wire vertical (2WV) and Geneva double curtain (GDC) trained muscadine grape vines at the UF/IFAS North Florida Research and Education Center in Monticello, FL, from 19781982.

\begin{tabular}{|c|c|c|c|c|c|c|c|c|}
\hline \multirow{2}{*}{$\begin{array}{l}\text { Muscadine } \\
\text { Cultivar }\end{array}$} & \multicolumn{3}{|c|}{ Yield (ton/acre) } & \multirow{2}{*}{$\begin{array}{c}\begin{array}{c}\text { Berry } \\
\text { Weight (g) }\end{array} \\
2 W V\end{array}$} & \multicolumn{2}{|c|}{ Soluble solids ( ${ }^{\circ}$ Brix) } & \multicolumn{2}{|c|}{ Berry No./Cluster } \\
\hline & GDC & $2 W V$ & GDC & & GDC & $2 W V$ & GDC & $2 W V$ \\
\hline \multicolumn{9}{|l|}{ BRONZE } \\
\hline Carlos & 6.5 & 8.3 & 5.0 & 5.5 & 14.3 & 15.3 & 9 & 8 \\
\hline Chowan & 1.8 & 2.2 & 5.9 & 5.6 & 16.7 & 15.8 & 8 & 10 \\
\hline Dearing & 3.6 & 3.9 & 3.2 & 3.0 & 18.1 & 14.5 & 9 & 10 \\
\hline Dixie & 7.4 & 7.3 & 4.0 & 5.1 & 17.7 & 15.4 & 11 & 10 \\
\hline Dixieland & 1.6 & 1.2 & 9.2 & 10.2 & 16.7 & 15.4 & 10 & 11 \\
\hline Dixie Red & 4.3 & 4.1 & 7.4 & 6.2 & 16.3 & 12.8 & 11 & 13 \\
\hline Fry & 5.5 & 4.4 & 13.9 & 12.4 & 16.2 & 15.9 & 10 & 9 \\
\hline Higgins & 10.2 & 6.7 & 8.5 & 7.6 & 15.6 & 14.1 & 10 & 8 \\
\hline Magnolia & 3.8 & 5.2 & 4.6 & 5.2 & 13.7 & 14.1 & 10 & 10 \\
\hline Pink Hunt & 2.3 & 2.0 & 5.3 & 5.4 & 15.9 & 14.2 & 7 & 8 \\
\hline Redgate & 6.0 & 6.1 & 3.5 & 3.5 & 15.8 & 15.6 & 15 & 13 \\
\hline Rich & 5.2 & 3.9 & 6.4 & 5.8 & 14.1 & 15.3 & 11 & 9 \\
\hline Roanoke & 2.7 & 5.6 & 5.7 & 4.9 & 12.4 & 11.9 & 9 & 11 \\
\hline Scuppernong & 3.5 & 3.5 & 5.2 & 4.9 & 13.9 & 13.9 & 12 & 10 \\
\hline Summit & 5.2 & 6.8 & 11 & 10.6 & 18.8 & 15.7 & 11 & 7 \\
\hline Topsail & 1.7 & 1.6 & 5.9 & 3.8 & 19.8 & 19.7 & 7 & 8 \\
\hline Watergate & 6.9 & 4.9 & 9.8 & 6.9 & 15.5 & 14.5 & 8 & 8 \\
\hline Welder & 7.2 & 5.7 & 3.7 & 3.2 & 17.1 & 17.3 & 9 & 10 \\
\hline Yuga & 7.0 & 4.1 & 3.8 & 3.0 & 16.6 & 15.3 & 13 & 12 \\
\hline \multicolumn{9}{|l|}{ BLACK } \\
\hline Albemarle & 6.0 & 5.1 & 5.5 & 5.8 & 17.5 & 16.0 & 6 & 7 \\
\hline Bountiful & 4.2 & 3.1 & 3.3 & 3.5 & 14.4 & 15.1 & 12 & 7 \\
\hline Chief & 6.8 & 5.4 & 3.6 & 3.3 & 15.4 & 15.7 & 9 & 8 \\
\hline Cowart & 7.2 & 7.2 & 6.8 & 7.5 & 14.3 & 14.3 & 8 & 8 \\
\hline Creek & 8.8 & 6.4 & 2.9 & 3.9 & 15.7 & 14.5 & 11 & 7 \\
\hline Hunt & 5.2 & 4.0 & 6.1 & 4.5 & 15.3 & 14.6 & 10 & 6 \\
\hline Jumbo & 7.4 & 7.4 & 15.3 & 13 & 13.5 & 14.3 & 8 & 7 \\
\hline Magoon & 4.0 & 6.1 & 3.4 & 3.4 & 15.6 & 17.9 & 10 & 10 \\
\hline Noble & 10.7 & 9.6 & 2.8 & 3.3 & 13.8 & 14.3 & 12 & 15 \\
\hline Pride & 6.7 & 3.4 & 9.1 & 9.2 & 14.6 & 15.0 & 7 & 9 \\
\hline Southland & 6.9 & 7.7 & 4.8 & 5.0 & 15.4 & 15.4 & 9 & 8 \\
\hline Sugargate & 1.6 & 2.1 & 10.1 & 12.0 & 19 & 16.5 & 7 & 8 \\
\hline
\end{tabular}


Table 2. Length, width, seed number, flavor rating, \% dry scar, and pH for 2-wire vertical and Geneva double curtain (GDC) and two-wire vertical (2WV) trained muscadine grape vines at the UF/IFAS NFREC-Monticello during 1980.

\begin{tabular}{|c|c|c|c|c|c|c|c|c|c|c|c|c|}
\hline \multirow{2}{*}{$\begin{array}{l}\text { Muscadine } \\
\text { Cultivar }\end{array}$} & \multicolumn{2}{|c|}{ Length (cm) } & \multicolumn{2}{|c|}{ Width (cm) } & \multicolumn{2}{|c|}{ Seeds (no.) } & \multirow[b]{2}{*}{ GDC } & \multirow{2}{*}{$\begin{array}{c}\text { Flavor }^{z} \\
2 W V\end{array}$} & \multicolumn{2}{|c|}{ \% Dry scar } & \multirow[b]{2}{*}{ GDC } & \multirow{2}{*}{$\begin{array}{r}\mathrm{pH} \\
2 \mathrm{WV}\end{array}$} \\
\hline & GDC & $2 W V$ & GDC & $2 W V$ & GDC & $2 W V$ & & & GDC & $2 W V$ & & \\
\hline \multicolumn{13}{|l|}{ Bronze } \\
\hline Carlos & 1.9 & 2.0 & 1.9 & 1.9 & 4.0 & 4.0 & 3.0 & 3.0 & 80.0 & 100.0 & 3.5 & 3.4 \\
\hline Chowan & 2.1 & 2.1 & 2.0 & 2.0 & 3.0 & 4.0 & 2.0 & 2.0 & 90.0 & 40.0 & 3.4 & 3.2 \\
\hline Dearing & 1.9 & 1.8 & 1.7 & 1.6 & 4.0 & 3.0 & 3.0 & & 60.0 & 100.0 & 3.6 & 3.2 \\
\hline Dixie & 1.8 & 2.0 & 1.9 & 1.9 & 4.0 & 4.0 & & 3.0 & 100.0 & 50.0 & 3.6 & 3.5 \\
\hline Dixieland & 2.5 & 2.6 & 2.5 & 2.6 & 4.0 & 4.0 & 3.0 & & 60.0 & 60.0 & 3.9 & \\
\hline Dixie Red & 2.5 & 2.4 & 2.3 & 2.2 & 3.0 & 3.0 & & & 90.0 & 100.0 & 3.7 & 3.7 \\
\hline Fry & 2.9 & 2.7 & 2.7 & 2.7 & 4.0 & 2.0 & 3.0 & 3.0 & 0.0 & 20.0 & 4.0 & 3.6 \\
\hline Higgins & 2.6 & 2.6 & 2.4 & 2.4 & 3.0 & 3.0 & & & 40.0 & 40.0 & 3.6 & 3.3 \\
\hline Magnolia & 2.1 & 2.0 & 1.9 & 1.9 & 3.0 & 3.0 & 4.0 & 4.0 & 40.0 & 20.0 & 3.4 & 3.6 \\
\hline Pink Hunt & 2.4 & 2.2 & 2.3 & 2.0 & 3.0 & 4.0 & 3.0 & 3.0 & 20.0 & 0.0 & 3.2 & 3.5 \\
\hline Redgate & 1.8 & 1.9 & 1.7 & 1.8 & 4.0 & 4.0 & 3.0 & & 80.0 & 100.0 & & 3.2 \\
\hline Rich & 2.2 & 2.1 & 2.1 & 2.0 & 4.0 & 4.0 & 2.0 & 2.0 & 60.0 & 80.0 & 3.3 & 3.3 \\
\hline Roanoke & 2.1 & 2.2 & 2.0 & 1.9 & 4.0 & 4.0 & 2.0 & 3.0 & 20.0 & 30.0 & 3.3 & 3.3 \\
\hline Scuppernong & 2.0 & 2.1 & 2.0 & 2.0 & 4.0 & 3.0 & 3.0 & 3.0 & 85.0 & 30.0 & 3.0 & 3.7 \\
\hline Summit & 2.6 & 2.7 & 2.5 & 2.5 & 3.0 & 3.0 & 3.0 & 4.0 & 60.0 & 60.0 & 4.1 & 3.8 \\
\hline Topsail & 2.1 & 1.9 & 2.0 & 1.8 & 2.0 & 3.0 & 3.0 & & 60.0 & 90.0 & 3.5 & 3.3 \\
\hline Watergate & 2.5 & 2.2 & 2.5 & 2.2 & 4.0 & 4.0 & 3.0 & 2.0 & 30.0 & 60.0 & 3.6 & 3.3 \\
\hline Welder & 1.9 & 1.8 & 1.7 & 1.7 & 4.0 & 4.0 & 3.0 & & 80.0 & 60.0 & 3.8 & 4.2 \\
\hline Yuga & 2.0 & 1.9 & 1.8 & 1.6 & 3.0 & 3.0 & & & 60.0 & 0.0 & 3.0 & 3.0 \\
\hline \multicolumn{13}{|l|}{ Black } \\
\hline Albemarle & 2.3 & 2.2 & 2.1 & 2.0 & 4.0 & 4.0 & 4.0 & 4.0 & 30.0 & 30.0 & 3.3 & 3.4 \\
\hline Bountiful & 1.8 & 1.7 & 1.6 & 1.7 & 3.0 & 3.0 & 3.0 & 3.0 & 20.0 & 60.0 & 3.2 & 3.2 \\
\hline Chief & 1.7 & 1.8 & 1.7 & 1.6 & 3.0 & 4.0 & 2.0 & 2.0 & 70.0 & 100.0 & 2.2 & 3.0 \\
\hline Cowart & 2.3 & 2.3 & 2.2 & 2.2 & 3.0 & 4.0 & 3.0 & 3.0 & 40.0 & 50.0 & 3.0 & 3.0 \\
\hline Creek & 1.7 & 1.9 & 1.6 & 2.0 & 4.0 & 3.0 & & 3.0 & 30.0 & 50.0 & 3.0 & 3.3 \\
\hline Hunt & 2.1 & 2.1 & 2.1 & 1.8 & 4.0 & 3.0 & 3.0 & 4.0 & 0.0 & 20.0 & 3.2 & 3.3 \\
\hline Jumbo & 2.9 & 3.0 & 2.8 & 2.7 & 4.0 & 3.0 & 3.0 & 3.0 & 20.0 & 20.0 & 3.4 & 3.8 \\
\hline Magoon & 1.7 & 1.7 & 1.6 & 1.6 & 4.0 & 3.0 & 3.0 & 3.0 & 40.0 & 40.0 & 3.0 & 2.7 \\
\hline Noble & 1.7 & 1.8 & 1.7 & 1.7 & 4.0 & 4.0 & 3.0 & & 20.0 & 50.0 & 3.2 & 3.6 \\
\hline Pride & 2.7 & 2.5 & 2.4 & 2.5 & 3.0 & 3.0 & 3.0 & 3.0 & 0.0 & 20.0 & 3.2 & 3.5 \\
\hline Southland & 2.0 & 2.0 & 1.9 & 1.9 & 4.0 & 4.0 & 3.0 & 3.0 & 100.0 & 60.0 & 3.1 & 3.2 \\
\hline Sugargate & 2.7 & 2.9 & 2.5 & 2.6 & 4.0 & 4.0 & & 3.0 & 60.0 & 40.0 & 3.6 & 3.5 \\
\hline
\end{tabular}


Table 3. Yield, berry weight, soluble solids, and \% dry scar of muscadine grape vines trained to a bilateral cordon system at the UF/ IFAS NFREC-Monticello from 1987-1991.

\begin{tabular}{|c|c|c|c|c|}
\hline Cultivar & Yield (tons/acre) ${ }^{z}$ & Berry Wt. (g) & Soluble solids ('Brix) & Dry scar (\%) \\
\hline \multicolumn{5}{|l|}{ Bronze } \\
\hline Carlos & 8.2 & 6.6 & 14.2 & 96 \\
\hline Dixie & 5.0 & 6.1 & 17.2 & 78 \\
\hline Excel & 5.5 & 10.0 & 14.4 & 84 \\
\hline Fry & 3.5 & 12.7 & 16.3 & 5 \\
\hline Golden Isles & 4.8 & & 14.7 & 91 \\
\hline Granny Val & 6.1 & 12.8 & 14.9 & 79 \\
\hline Magnolia & 6.3 & 6.4 & 13.9 & 73 \\
\hline Senoria & 5.7 & 8.5 & 14.3 & 87 \\
\hline Summit & 3.8 & 10.0 & 16.2 & 90 \\
\hline Tara & 2.5 & 11.0 & 16.2 & 95 \\
\hline Welder & 6.1 & 4.2 & 13.6 & 88 \\
\hline \multicolumn{5}{|l|}{ Black } \\
\hline Alachuaz & 2.8 & 8.0 & 17.7 & 98 \\
\hline Albemarle & 2.8 & 6.5 & 16.9 & 88 \\
\hline Cowart & 4.1 & 8.3 & 14.0 & 79 \\
\hline Farrer & 4.8 & 13.4 & 15.2 & 0 \\
\hline Jumbo & 3.2 & 13.4 & 14.1 & 74 \\
\hline Loomis $^{z}$ & 0.2 & 9.8 & 15.1 & 70 \\
\hline Noble & 7.5 & 4.1 & 14.7 & 56 \\
\hline Polyannaz & 3.3 & 10.8 & 18.8 & 92 \\
\hline Southern home & 3.3 & 6.8 & 19.1 & 98 \\
\hline
\end{tabular}


Table 4. Average vine vigor, yield, berry wt., and soluble solids at the UF/IFAS NFREC-Quincy from 2002-2005.

\begin{tabular}{|c|c|c|c|c|}
\hline Cultivar & Vigor estimate & $\begin{array}{c}\text { Yield } \\
\text { estimate }^{z}\end{array}$ & Berry wt. (g) & $\begin{array}{c}\text { Soluble } \\
\text { Solids } \\
\text { ( }{ }^{\circ} \text { Brix) }\end{array}$ \\
\hline Alachua & 7.6 & 7.3 & 6.5 & 17.5 \\
\hline Black Beauty & 7.0 & 6.9 & 11.9 & 17.3 \\
\hline Black Fry & 5.8 & 5.7 & 10.6 & 17.7 \\
\hline Carlos & 8.8 & 8.7 & 5.4 & 17.4 \\
\hline Creek & 7.6 & 7.9 & 3.0 & 15.1 \\
\hline Early Fry & 4.4 & 4.2 & 10.2 & 17.4 \\
\hline Fry & 5.1 & 6.3 & 10.4 & 18.8 \\
\hline Granny Val & 6.9 & 7.4 & 11.0 & 17.0 \\
\hline Jumbo & 6.7 & 6.7 & 9.8 & 15.1 \\
\hline Noble & 8.9 & 9.4 & 3.2 & 16.8 \\
\hline Pam & 7.9 & 6.3 & 12.7 & 16.1 \\
\hline Pineapple & 6.0 & 6.8 & 8.7 & 15.7 \\
\hline Polyanna & 7.4 & 7.1 & 9.3 & 18.2 \\
\hline Regale & 7.5 & 8.2 & 5.3 & 14.7 \\
\hline Scarlett & 8.0 & 5.6 & 10.6 & 18.9 \\
\hline Summitt & 8.5 & 7.4 & 8.1 & 18.7 \\
\hline Supreme & 4.8 & 6.3 & 11.9 & 15.2 \\
\hline Sweet Jenny & 7.2 & 6.4 & 12.6 & 16.7 \\
\hline Tara & 7.3 & 5.9 & 9.3 & 15.6 \\
\hline Triumph & 7.0 & 5.8 & 8.2 & 17.4 \\
\hline Lsd $0.05^{y}$ & 1.5 & 1.6 & 0.8 & 1.6 \\
\hline
\end{tabular}


Table 5. Summary of vegetative and reproductive characteristics of muscadine grape cultivars.

\begin{tabular}{|c|c|c|c|c|c|c|c|c|c|c|}
\hline \multirow{2}{*}{$\begin{array}{l}\text { Muscadine } \\
\text { Cultivar }^{z}\end{array}$} & \multirow[t]{2}{*}{ Yield } & \multirow{2}{*}{$\begin{array}{l}\text { Flower } \\
\text { Type }\end{array}$} & \multicolumn{2}{|c|}{ Fruit Size } & \multirow{2}{*}{$\begin{array}{l}\text { Soluble } \\
\text { Solids }\end{array}$} & \multirow{2}{*}{$\begin{array}{c}\text { Disease } \\
\text { Resistance }^{y}\end{array}$} & \multirow[t]{2}{*}{ Vigor $^{x}$} & \multirow{2}{*}{$\begin{array}{l}\text { Harvest } \\
\text { Season }\end{array}$} & \multirow{2}{*}{$\begin{array}{l}\text { Dry Scar } \\
\text { (\%) }\end{array}$} & \multirow{2}{*}{$\begin{array}{c}\text { Recommendation } \\
\text { Status }^{w}\end{array}$} \\
\hline & & & (in) & $(g)$ & & & & & & \\
\hline \multicolumn{11}{|l|}{ Bronze } \\
\hline Carlos & $\mathrm{VH}$ & SF & 0.5 & 5.0 & 15 & F-G & $\mathrm{H}$ & Early-Mid & 82 & $\mathrm{R}$ \\
\hline Chowan & $\mathrm{L}$ & SF & 0.5 & 5.0 & 16 & & & & 50 & NR \\
\hline Darlene & $M$ & $\mathrm{~F}$ & 1.5 & 15.0 & 22 & G & $\mathrm{H}$ & Early-Mid & 90 & $\mathrm{~T}$ \\
\hline Dearing & $M$ & SF & 0.67 & 4.0 & 15 & & & & & NR \\
\hline Delight & $\mathrm{MH}$ & SF & 1 & 10.0 & 14 & & $\mathrm{~L}$ & Mid-Late & 84 & NR \\
\hline Dixie & $\mathrm{H}$ & SF & 0.5 & 5.0 & 15 & & & & 20 & NR \\
\hline Dixieland & $\mathrm{L}$ & SF & 1.25 & 12.5 & 15 & $\mathrm{~F}$ & $\mathrm{VL}$ & Early-Mid & 21 & NR \\
\hline Dixie Red & $M$ & SF & 1 & 10.0 & 13 & $F-G$ & $\mathrm{MH}$ & Mid & 21 & NR \\
\hline Doreen & $\mathrm{H}$ & SF & 0.5 & 5.0 & 18 & G & $\mathrm{L}$ & Late & & $\mathrm{T}$ \\
\hline Early Fry & VH & $\mathrm{F}$ & 1.25 & 12.5 & 18 & $E$ & $\mathrm{H}$ & Very Early & 66 & $\mathrm{~T}$ \\
\hline Florida Fry & $\mathrm{MH}$ & SF & 1.13 & 11.5 & 18 & $E$ & $M$ & Mid-Late & & $\mathrm{T}$ \\
\hline Fry & $M$ & $\mathrm{~F}$ & 1.25 & 12.5 & 16 & $\mathrm{~F}$ & $\mathrm{~L}$ & Early-Mid & 52 & $\mathrm{R}$ \\
\hline Fry Seedless & $\mathrm{L}$ & $\mathrm{F}$ & 0.5 & 5.0 & 18 & $E$ & $\mathrm{H}$ & Early-Mid & 20 & NR \\
\hline Golden Isles & $M$ & SF & 0.67 & 6.5 & 15 & $\mathrm{G}$ & $\mathrm{H}$ & Late & 94 & $\mathrm{~T}$ \\
\hline Granny Val & $\mathrm{VH}$ & SF & 1.25 & 12.5 & 16 & G & $\mathrm{L}$ & Late & 94 & $\mathrm{R}$ \\
\hline Higgins & VH & $\mathrm{F}$ & 1.13 & 11.5 & 14 & F-G & $M$ & Mid-Late & 20 & NR \\
\hline Janebell $^{\mathrm{P}}$ & $\mathrm{H}$ & SF & 1 & 10.0 & 16 & $F-G$ & $\mathrm{H}$ & Early-Mid & 44 & NR \\
\hline Janet & $\mathrm{MH}$ & $\mathrm{F}$ & 1.13 & 11.5 & 21 & $\mathrm{G}$ & $\mathrm{H}$ & Mid & 35 & NR \\
\hline Late Fry & $\mathrm{H}$ & SF & 1.5 & 15.0 & 20 & $E$ & $\mathrm{H}$ & Very Late & 95 & $\mathrm{~T}$ \\
\hline Magnolia & M & SF & 0.5 & 5.0 & 14 & & $\mathrm{MH}$ & Mid & 15 & NR \\
\hline $\operatorname{Pam}^{P}$ & $\mathrm{VH}$ & $\mathrm{F}$ & 1.5 & 15.0 & 21 & $E$ & $\mathrm{H}$ & Early-Mid & 87 & $\mathrm{R}$ \\
\hline Pineapple & $\mathrm{VH}$ & SF & 1 & 10.0 & 16 & $E$ & $\mathrm{H}$ & Mid-Late & 47 & $\mathrm{R}$ \\
\hline Pink Hunt & & SF & & & 14 & & & & & NR \\
\hline Redgate & & SF & 0.75 & 7.5 & 16 & & $\mathrm{H}$ & Mid-Late & & NR \\
\hline Rich & & & 0.79 & 8.0 & 15 & & & & & NR \\
\hline Roanoke & $\mathrm{M}$ & SF & 0.79 & 8.0 & 12 & & & & 25 & NR \\
\hline Rosa & $\mathrm{MH}$ & $\mathrm{F}$ & 1.13 & 11.5 & 18 & G & $\mathrm{H}$ & Mid & 70 & NR \\
\hline Scuppernong & LM & $\mathrm{F}$ & 0.5 & 5.0 & 14 & $\mathrm{~F}-\mathrm{G}$ & $M$ & Mid & 38 & NR \\
\hline Sterling & $\mathrm{H}$ & SF & 0.67 & 6.5 & & & $M$ & Mid & & NR \\
\hline Sugar Pop & & $\mathrm{F}$ & 1.25 & 12.5 & & & $\mathrm{H}$ & Mid-Late & & NR \\
\hline Summit & $\mathrm{MH}$ & $\mathrm{F}$ & 1 & 10.0 & 16 & G & $\mathrm{F}$ & Mid & 82 & $\mathrm{R}$ \\
\hline Sweet Jenny & $\mathrm{MH}$ & $\mathrm{F}$ & 1.5 & 15.0 & 23 & $\mathrm{~F}$ & $\mathrm{H}$ & Early-Mid & 80 & $\mathrm{R}$ \\
\hline Tara & LM & SF & 1 & 10.0 & 17 & G & $\mathrm{MH}$ & Mid & 91 & $\mathrm{R}$ \\
\hline Topsail & $\mathrm{L}$ & SF & 0.73 & 7.5 & 20 & & & & & NR \\
\hline Triumph & $M$ & SF & 1 & 10.0 & 18 & $\mathrm{~F}-\mathrm{G}$ & $M$ & Early-Mid & 90 & NR \\
\hline Watergate & $\mathrm{MH}$ & $\mathrm{F}$ & 0.87 & 8.5 & 15 & & $M$ & Mid & & NR \\
\hline Welder & $\mathrm{H}$ & SF & 0.67 & 6.5 & 17 & $\mathrm{G}$ & $M$ & Mid & & $\mathrm{R}$ \\
\hline Yuga & $\mathrm{MH}$ & SF & 0.67 & 6.5 & 15 & & & & & NR \\
\hline \multicolumn{11}{|l|}{ Black } \\
\hline African Queen & & $\mathrm{F}$ & 1.13 & 11.5 & & & $\mathrm{H}$ & Mid & Dry & \\
\hline Alachua & $M$ & SF & 0.67 & 6.5 & 18 & $\mathrm{G}$ & M & Early-Mid & & NR \\
\hline Albemarle & $M$ & SF & 0.67 & 6.5 & 16 & & & & & NR \\
\hline Big Red & & $\mathrm{F}$ & 1.25 & 12.5 & & & $\mathrm{VL}$ & Mid-Late & & $\mathrm{T}$ \\
\hline
\end{tabular}




\begin{tabular}{|c|c|c|c|c|c|c|c|c|c|c|}
\hline Black Beauty & $M$ & $\mathrm{~F}$ & 1.25 & 12.5 & 23 & $\mathrm{E}$ & $M$ & Early-Mid & 78 & $\mathrm{R}$ \\
\hline Black Fry & $M$ & $\mathrm{~F}$ & 1.25 & 12.5 & 19 & $E$ & $M$ & Early-Mid & 64 & $\mathrm{R}$ \\
\hline Bountiful & $M$ & SF & 0.67 & 6.5 & 15 & & & & & NR \\
\hline Chief & $\mathrm{H}$ & SF & 0.67 & 6.5 & 16 & & & & & NR \\
\hline Cowart & $M$ & SF & 0.75 & 7.5 & 14 & $\mathrm{G}$ & $M$ & Mid & & NR \\
\hline Creek & $\mathrm{VH}$ & SF & 0.79 & 8.0 & 15 & & & & & NR \\
\hline Delicious & $\mathrm{H}$ & SF & 1 & 10 & 17 & $E$ & M & Early-Mid & 90 & $\mathrm{~T}$ \\
\hline Eudora & $\mathrm{H}$ & $\mathrm{F}$ & 1 & 10 & 17 & $E$ & $\mathrm{MH}$ & Mid-Late & 70 & $\mathrm{~T}$ \\
\hline Farrer $^{p}$ & M & $\mathrm{F}$ & 1.25 & 12.5 & 18 & G & $\mathrm{H}$ & Mid-Late & & $\mathrm{R}$ \\
\hline Georgia Red & & $\mathrm{F}$ & & & & & $\mathrm{H}$ & Mid & & NR \\
\hline Hunt & $M$ & $\mathrm{~F}$ & 1 & 10.0 & 15 & $\mathrm{~F}-\mathrm{G}$ & $\mathrm{MH}$ & Early-Mid & & NR \\
\hline Ison & $\mathrm{VH}$ & SF & 1.13 & 11.5 & 19 & $\mathrm{E}$ & $\mathrm{VH}$ & Early-Mid & 92 & $\mathrm{~T}$ \\
\hline Jumbo & M & $\mathrm{F}$ & 1.5 & 15.0 & 14 & G & $\mathrm{H}$ & Mid & 74 & NR \\
\hline Loomis & $\mathrm{L}$ & $\mathrm{F}$ & 1.13 & 11.5 & & & $\mathrm{H}$ & Mid-Late & & NR \\
\hline Magoon & M & SF & & & 18 & & & & & NR \\
\hline Majesty & $\mathrm{H}$ & $\mathrm{F}$ & 1.5 & 16 & 15 & $\mathrm{G}$ & $\mathrm{H}$ & & Dry & $\mathrm{T}$ \\
\hline Nesbitt & $\mathrm{H}$ & SF & 1.13 & 11.5 & 18 & G & $\mathrm{H}$ & Mid-Late & 41 & $\mathrm{~T}$ \\
\hline Noble & $\mathrm{H}$ & SF & $0.25-0.5$ & 4.0 & 14 & $\mathrm{G}$ & $\mathrm{MH}$ & Early-Mid & $\mathrm{H}$ & $\mathrm{R}$ \\
\hline Polyanna & $\mathrm{H}$ & SF & 1 & 9.5 & 17 & $\mathrm{E}$ & $\mathrm{H}$ & Late & & $\mathrm{R}$ \\
\hline Pride & $M$ & & 0.98 & 9.0 & 15 & & & & & NR \\
\hline Redgate & & SF & 0.71 & 7.0 & & & $\mathrm{H}$ & Mid-Late & & NR \\
\hline Scarlet & M & $\mathrm{F}$ & 1.13 & 11.5 & 17 & $\mathrm{G}$ & $\mathrm{M}$ & Mid & 72 & NR \\
\hline $\begin{array}{l}\text { Southern } \\
\text { Home }^{p}\end{array}$ & $M$ & SF & 0.67 & 6.5 & 19 & G & $\mathrm{MH}$ & Mid & & $\mathrm{R}$ \\
\hline Southern Jewel & $\mathrm{H}$ & SF & 1.13 & 11 & 16 & $\mathrm{G}$ & M & Early & 75 & $\mathrm{~T}$ \\
\hline Southland & $\mathrm{MH}$ & SF & 0.5 & 5.0 & 17 & $\mathrm{G}$ & $\mathrm{MH}$ & Mid-Late & 51 & NR \\
\hline Sugargate & $\mathrm{L}$ & $\mathrm{F}$ & 1.25 & 12.5 & 17 & $E$ & $\mathrm{M}$ & Early-Mid & 60 & NR \\
\hline Supreme & $\mathrm{H}$ & $\mathrm{F}$ & 1.5 & 15.0 & 22 & $E$ & VL & Mid-Late & 94 & $\mathrm{R}$ \\
\hline \multicolumn{11}{|c|}{$\begin{array}{l}{ }^{\text {z Cultivars: }}{ }^{p}=\text { Patented. } \\
\text { y Disease resistance: } F=\text { Fair, } G=\text { Good, } E=\text { Excellent. } \\
\text { ×Vigor: } V L=\text { Very Low, } L=L \text { Low } M=\text { Medium, } H=\text { High. } \\
{ }^{w} \text { Recommendation status: } N R=\text { Not Recommended, } T=\text { Recommended for Trail, } R=\text { Recommended. }\end{array}$} \\
\hline
\end{tabular}

